\title{
The influence of natural dissolved organic matter on herbicide toxicity to marine microalgae is species- dependent
}

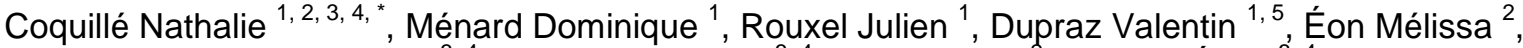 \\ Pardon Patrick ${ }^{3,4}$, Budzinski Hélène ${ }^{3,4}$, Morin Soizic ${ }^{2}$, Parlanti Édith ${ }^{3,4}$, \\ Stachowski-Haberkorn Sabine ${ }^{1}$
}

${ }^{1}$ Ifremer, Laboratoire d'Écotoxicologie, rue de l'île d'Yeu, BP 21105, F-44311 Nantes Cedex 03, France

2 Irstea, UR EABX, Centre de Bordeaux, 50 avenue de Verdun, F-33612 Cestas Cedex, France

${ }^{3}$ Univ. Bordeaux, UMR 5805 CNRS, EPOC, LPTC, 351 Cours de la Libération, CS 10004, F-33405

Talence Cedex, France

${ }^{4}$ CNRS, UMR 5805, EPOC, LPTC, 351 Cours de la Libération, CS 10004, F-33405 Talence Cedex, France

${ }^{5}$ Université de Nantes, UFR Sciences et Techniques, 2, rue de la Houssinière, BP 92208, 44322

Nantes Cedex 03, France

*Corresponding author : Nathalie Coquillé, email address : nathalie.coquille@gmail.com

\begin{abstract}
:
Microalgae, which are the foundation of aquatic food webs, may be the indirect target of herbicides used for agricultural and urban applications. Microalgae also interact with other compounds from their environment, such as natural dissolved organic matter (DOM), which can itself interact with herbicides. This study aimed to evaluate the influence of natural DOM on the toxicity of three herbicides (diuron, irgarol and S-metolachlor), singly and in ternary mixtures, to two marine microalgae, Chaetoceros calcitrans and Tetraselmis suecica, in monospecific, non-axenic cultures. Effects on growth, photosynthetic efficiency $\left(\Phi^{\prime} M\right)$ and relative lipid content were evaluated. The chemical environment (herbicide and nutrient concentrations, dissolved organic carbon and DOM optical properties) was also monitored to assess any changes during the experiments.
\end{abstract}

The results show that, without DOM, the highest irgarol concentration (10.5: $0.5 \mathrm{mg} \mathrm{L}-1$ ) and the strongest mixture (M2: irgarol $0.5 \mu \mathrm{g} \mathrm{L}-1$ + diuron $0.5 \mu \mathrm{g} \mathrm{L}-1+\mathrm{S}$-metolachlor $5.0 \mu \mathrm{g} \mathrm{L}-1$ ) significantly decreased all parameters for both species. Similar impacts were induced by 10.5 and M2 in $C$. calcitrans (around $-56 \%$ for growth, $-50 \%$ for relative lipid content and $-28 \%$ for $\Phi ' M$ ), but a significantly higher toxicity of M2 was observed in T. suecica ( $-56 \%$ and $-62 \%$ with 10.5 and $\mathrm{M} 2$ for growth, respectively), suggesting a possible interaction between molecules.

With DOM added to the culture media, a significant inhibition of these three parameters was also observed with 10.5 and $\mathrm{M} 2$ for both species. Furthermore, DOM modulated herbicide toxicity, which was decreased for $C$. calcitrans ( $-51 \%$ growth at 10.5 and M2) and increased for $T$. suecica $(-64 \%$ and $-75 \%$ 
growth at 10.5 and $\mathrm{M} 2$, respectively).

In addition to the direct and/or indirect (via their associated bacteria) use of molecules present in natural DOM, the characterization of the chemical environment showed that the toxic effects observed on microalgae were accompanied by modifications of DOM composition and the quantity of dissolved organic carbon excreted and/or secreted by microorganisms. This toxicity modulation in presence of DOM could be explained by (i) the modification of herbicide bioavailability, (ii) a difference in cell wall composition between the two species, and/or (iii) a higher detoxification capacity of C. calcitrans by the use of molecules contained in DOM. This study therefore demonstrated, for the first time, the major modulating role of natural DOM on the toxicity of herbicides to marine microalgae.

\section{Highlights}

- Two marine microalgae were exposed to irgarol, diuron and S-metolachlor and DOM. Influence of natural DOM was evaluated on herbicide toxicity, singly and in mixtures. Growth, photosynthetic efficiency and lipid content were influenced by herbicides. Excreted molecules (quantity and composition) were influenced by herbicides. Natural DOM modulated herbicide toxicity in a speciesdependent way.

Keywords : Microalgae, Herbicides, Natural dissolved organic matter, DOM, Toxicity, Interactions 


\section{Introduction}

Pesticides (herbicides, fungicides, insecticides, etc) are substances used to control, destroy and repel any organism considered to be harmful (FAO, 2003). These substances are grouped into two categories according to their use: phytosanitary, intended to protect plants or plant products against pests and mainly used in agriculture, and biocides, intended for all other uses (sanitary, protection of materials, repellents, piscicides, insecticides) (Directive n॰98/8/CE, European Union, 1998). These molecules are transferred to nearby rivers by natural phenomena such as soil leaching, runoff and drainage (Mai et al., 2013), down to estuaries and the coast, both of which are areas with key ecological roles. Estuaries and coasts fulfil many services and functions, both economic (tourism, fishing, aquaculture) and biological (areas of refuge, reproduction, spawning, nursery) (Boehlert and Mundy, 1988; Dauvin et al., 2002). Their importance results from their ecotone position (transition zone) between terrestrial, fluvial and marine ecosystems.

Coastal and estuarine areas are the ultimate recipients of both natural and anthropogenic inputs, including pesticides and organic matter from continental ecosystems and rivers (Mitra and Zaman, 2016; Rajasekaran et al., 2005). Terrestrial organic matter inputs (namely allochthonous), composed of particulate $(>0.45 \mu \mathrm{m})$ and dissolved matter $(<0.45 \mu \mathrm{m})$, favour biological production. Indeed, organic matter, being mainly dissolved in aquatic ecosystems (Findlay and Sinsabaugh, 2003), constitutes a significant source of organic nutrients (composed of phosphorus, nitrogen and silica among other elements) essential for coastal and estuarine phytoplanktonic blooms (Gailhard, 2003; Hansell and Carlson, 2014). In addition to terrigenous dissolved organic matter (DOM) inputs, estuarine and coastal environments have a high production of autochthonous DOM. Indeed, in temperate latitudes during spring (at the end of phytoplanktonic blooms), summer and autumn, microalgal excretion together with decomposition of dead microalgae by bacteria, are the main sources of autochthonous DOM production (Findlay and Sinsabaugh, 2003). DOM production, degradation and fate are therefore tightly linked to microorganisms in coastal environments, including phytoplankton. 
Phytoplankton play a key role in marine ecosystems. As primary producers, they synthesize organic carbon through photosynthesis (Hall and Rao, 1999) and are thus at the base of aquatic food webs (Wetzel, 2001). These planktonic organisms, whose development relies directly on the quality of their environment, are sensitive to key parameters such as temperature, light and nutrient availability. They can be negatively affected by a high concentration of coloured organic matter due to decreased light penetration through the water column (Karlsson et al., 2009), but also by pesticides and more specifically by herbicides, due to the mode of action of these chemicals (especially photosynthesis inhibition; Pesce et al., 2009).

Coastal areas, estuaries and bays, such as Arcachon Bay (southwest France), have been contaminated by a diversity of pesticides, especially herbicides, due to large scale agriculture on the watersheds (Fauvelle, 2012; SOeS, 2015). S-metolachlor (chloroacetanilide), one of the herbicides the most used for corn and other crops (Sjollema et al., 2014), is the fourth most detected molecule in surface waters of French streams (SOeS, 2015). In Arcachon Bay, the contamination footprint shows that, together with its metabolites (ESA and OA), Smetolachlor is detected the most frequently and at the highest concentrations (peak concentration of $0.526 \mu \mathrm{g} . \mathrm{L}^{-}$ 1) (REPAR, 2015; Tapie et al., 2016). Because metolachlor occurrence is so widespread in waters, it should be asked whether it is toxic towards aquatic organisms. Its mode of action is based on inhibition of fatty acid and lipid synthesis (Fuerst, 1987; Schmalfuß et al., 1998). Even though these biological compounds are major components of cell walls and energy storage (Borowitzka et al., 2016), inhibition of their synthesis does not seem to lead to high toxicity in microalgae, as most studies have only shown toxic effects in the mg. $\mathrm{L}^{-1}$ range. For example, Ebenezer and Ki (2013) measured a 50\% decrease of chlorophyll $a$ levels with 0.423 mg.L. ${ }^{-1}$ and $21.3 \mathrm{mg} . \mathrm{L}^{-1}$ metolachlor for the marine diatom Ditylum brightwellii and the marine chlorophyte Tetraselmis suecica, respectively. Thakkar et al. (2013) showed a decrease in growth (-9\%) and chlorophyll $a$ fluorescence ($35 \%$ ) in the chlorophyte Dunaliella tertiolecta after exposure to $5.0 \mathrm{mg} . \mathrm{L}^{-1}$ metolachlor. However, some sublethal effects were demonstrated at lower concentrations: Roubeix et al. (2011) observed a significant increase in the quantity of deformed frustules of the microalga Surirella angusta (around 20\%o) at $5 \mu$ g.L. $\mathrm{L}^{-1} \mathrm{~S}$ metolachlor.

Nautical activities (recreation and fishing) also cause pollution, due to biocides such as diuron and irgarol that are used as antifouling coating on boats (Fauvelle, 2012; REPAR, 2015) Diuron is a phenylurea, presently still authorized as an antifoaming agent, but previously also used in agriculture and antifouling paints in France (Biocides Directive 98/8/EC and Decree of 21/08/2008) and irgarol is a triazine used in antifouling paints that has been prohibited in European Union since 2016 (Commission implementing decision $\mathrm{n}^{\circ} 2016 / 107$ of 27/01/2016). For these two substances, environmental concentrations, including those in Arcachon Bay, are usually in the ng. $\mathrm{L}^{-1}$ range (Munaron et al., 2012; REPAR, 2015; Tapie et al., 2016). However, Caquet et al. (2013) found irgarol concentrations of up to of $1 \mu \mathrm{g} . \mathrm{L}^{-1}$ in the Vilaine River estuary, and Cozic and Durand (2013) measured maximal irgarol and diuron concentrations of $0.82 \mu \mathrm{g} . \mathrm{L}^{-1}$ and $2.58 \mu \mathrm{g} . \mathrm{L}^{-1}$, respectively, in careening areas of several French ports. Both substances inhibit the photosynthesis, preventing electron transfer between quinones $\mathrm{Q}_{\mathrm{A}}$ and $\mathrm{Q}_{\mathrm{B}}$ by fixing to the D1 protein in photosystem II (PSII) (Jones and Kerswell, 2003; Nimbal et al., 1996). Their strong toxicity to microalgae has been documented for several species: Gatidou and Thomaidis (2007) obtained a $96 \mathrm{~h}-\mathrm{EC}_{50}$ for growth (the concentration that inhibits growth by $50 \%$ after $96 \mathrm{~h}$ ) of $0.6 \mu \mathrm{g} . \mathrm{L}^{-1}$ irgarol for the marine diatom Navicula forcipata and $5.9 \mu \mathrm{g} . \mathrm{L}^{-1}$ diuron for the marine chlorophyte 
Dunaliella tertiolecta. Buma et al. (2009) obtained 72h-EC 50 values for growth and effective quantum yield of 0.116 and $0.230 \mu \mathrm{g} . \mathrm{L}^{-1}$ irgarol, respectively, for the marine chlorophyte Tetraselmis sp., and Bao et al. (2011) obtained $96 \mathrm{~h}-\mathrm{EC}_{50}$ values for growth of $0.57 \mu \mathrm{g} . \mathrm{L}^{-1}$ irgarol and $5.9 \mu \mathrm{g} . \mathrm{L}^{-1}$ diuron for the marine diatom Skeletonema costatum.

In the environment, other components like DOM can influence pesticides, microalgae and their relationships. Indeed, DOM is well known to influence the transport, fate, bioavailability, biodegradation and toxicity of pesticides in the aquatic environment (Bejarano et al., 2005). Several studies on animals have shown that pesticide toxicity can be increased or decreased by the presence of DOM, depending on the molecules and organisms tested (see review in Haitzer et al., 1998). For example, Bejarano et al. (2005) showed that a natural DOM concentration around $12 \mathrm{mgC} . \mathrm{L}^{-1}$ increased the toxicity of fipronil to the estuarine copepod Amphiascus tenuiremis, but decreased the toxicity of chlorpyrifos and chlorothalonil. In the same way, Zhang et al. (2016b) showed an increase of monochlorobenzene and 1,2-dichlorobenzene toxicity and a decrease of pentachlorobenzene and hexachlorobenzene toxicity to growth of the freshwater microalga Chlorella pyrenoidosa with addition of Suwannee River Natural Organic Matter (SRNOM - reference material of the International Humic Substances Society (IHSS)) (around $10 \mathrm{mgC.L}^{-1}$ ). However, to our knowledge, no other study has focused on the crossed impact of herbicides and natural DOM on microalgae. Therefore, the present study aimed:

- to evaluate the influence of three herbicides (diuron, irgarol and S-metolachlor), singly and in ternary mixtures, on two marine microalgae;

- to investigate the influence of natural DOM on herbicide toxicity.

Two marine microalgae species (Chaetoceros calcitrans and Tetraselmis suecica) were exposed for six days to the three herbicides, either singly or in mixtures, and either with or without natural DOM concentrated from marine water. Effects were evaluated on growth, photosynthetic efficiency and relative intracellular lipid content. At the same time, the chemical environment (herbicide and nutrient concentrations, dissolved organic carbon concentration (DOC) and DOM optical properties) was also characterized to evaluate any changes taking place during the experiments.

\section{Materials and methods}

\subsection{Chemical preparation}

Irgarol (Pestanal ${ }^{\circledR} \geq 98.4 \%$; 2-(tert-Butylamino)-4-(cyclopropylamino)-6-(methylthio)-s-triazine), diuron (>98\%; 3-(3,4-dichlorophenyl)-1,1-dimethylurea), and S-metolachlor $\quad$ (Pestanal ${ }^{\circledR} \geq 98.4 \%$; 2-chloro-N-(2-ethyl-6methylphenyl)-N-[(1S)-2-methoxy-1-methylethyl]acetamide) were purchased from Sigma Aldrich. Stock solutions of each $\left(500 \mathrm{mg} . \mathrm{L}^{-1}\right)$ were prepared in pure methanol and diluted in sterile ultrapure water to make working solutions of 0.002 (0.0004\% methanol), 0.02 (0.004\% methanol), 0.006 (0.0012\% methanol) and $0.06 \mathrm{mg} . \mathrm{L}^{-1}(0.012 \%$ methanol) for irgarol and diuron, and 0.02 (0.004\% methanol), $0.2(0.04 \%$ methanol), 0.06 (0.012\% methanol) and $0.6 \mathrm{mg} . \mathrm{L}^{-1}(0.12 \%$ methanol) for S-metolachlor.

\section{2. $\quad$ Natural DOM}

In order to obtain a final concentration of DOM in the experiment that was equal to twice the environmental concentration at the date of DOM sampling (environmentally realistic), DOM was concentrated as follows. In 
spring 2015, $91 \mathrm{~L}$ of natural seawater were pumped from the Grand Banc site in Arcachon Bay (France) at $1.50 \mathrm{~m}$ depth at high tide to avoid the influence of freshwater inputs. Immediately on return to the laboratory, the seawater was filtered through $0.45-\mu \mathrm{m}$ Teflon filter cartridges (Whatman, Polycap ${ }^{\mathrm{TM}} 75 \mathrm{TF}$ ) to remove particulate organic matter. All filters were pre-cleaned with methanol $(0.4 \mathrm{~L})$ then rinsed firstly with $5 \mathrm{~L}$ ultrapure water (Milli-Q, Millipore) and secondly with the water sample $(1 \mathrm{~L})$. The $0.45-\mu \mathrm{m}$ filtered seawater was first desalted by electrodialysis (ED; EURODIA Aqualyzer pilot EUR2B-10P equipped with Neosepta AMX/CMX membranes from the Tokuyama Corporation, Japan). The desalted water was then concentrated by reverse osmosis (RO; TIA pilot equipped with FILMTEC ${ }^{\mathrm{TM}}$ SW30-2540 membrane) about ten times until a final volume of $9.5 \mathrm{~L}$ was reached and finally desalted again to reach a salinity of 33 (corresponding to the salinity of f/2 culture medium (Guillard, 1975; Guillard and Ryther, 1962) used to grow marine microalgae). During the steps of concentration (RO) and desalination (ED), the sample temperature was controlled in order to minimize any possible change of DOM. The maximum temperature reached during the diverse experimental procedures did not exceed $24^{\circ} \mathrm{C}$. DOM quality was checked by excitation-emission-matrix (EEM) fluorescence before and after concentration and desalination. Only slight differences in spectra were observed, pointing out that no selective loss or modification of fluorescent organic compounds occurred during the RO/ED process (data not shown). The final concentrated and desalted samples were thus representative of the original ones. More details on the protocols and systems used can be found in Huguet (2007) and Huguet et al. (2009a). Finally, the concentrations of the three herbicides studied were also measured in these seawater samples before and after DOM concentration to confirm the absence of high herbicide concentrations. Details on the pesticide measurement protocol are given in section 2.6.2.

\subsection{Microalgal cultures}

The microalgae Tetraselmis suecica (CCMP 904, Chlorophyta) and Chaetoceros calcitrans (CCMP 1315, Bacillariophyta) were obtained from the Provasoli-Guillard National Center for Marine Algae and Microbiota (NCMA). Microalgal cultures were maintained in sterile $\mathrm{f} / 2$ (for $T$. suecica) and f/2-silica medium (for $C$. calcitrans) (Guillard, 1975; Guillard and Ryther, 1962) at $17^{\circ} \mathrm{C}$, in a thermostatic chamber ST5+ (POL-EKOAparatura $^{\circledR}$, Poland) at $106 \pm 0 \mu \mathrm{mol} \cdot \mathrm{m}^{-2} \cdot \mathrm{s}^{-1}$ with a dark:light cycle of 8:16 h. Cultures were non-axenic.

All cultures were grown in $100-\mathrm{mL}$ round borosilicate sterile glass flasks previously heated to $450^{\circ} \mathrm{C}$ for $6 \mathrm{~h}$ and autoclaved 20 minutes at $121^{\circ} \mathrm{C}$. For the experiments, cultures $(60 \mathrm{~mL}$ volume $)$ were inoculated at 20,000 cell. $\mathrm{mL}^{-1}$ using stock cultures in exponential growth phase.

\subsection{Experimental design}

Two independent experiments (one per species) were run for six days, each with a biotic and an abiotic component (with and without microalgae). For each experiment, the crossed influence of DOM (conditions with and without DOM) and pesticides (nine treatments per condition, including a control) was tested on microalgae, as follows. Half of the flasks were filled with culture medium while the other half were filled with culture medium together with DOM added at twice the environmental concentration. Nutrient enrichment was adjusted in conditions with and without DOM to obtain the same final concentration in all flasks. For flasks with culture medium and culture medium + DOM, treatments included a control (no pesticide) in quadruplicate, plus eight pesticide treatments in triplicate: irgarol at 0.05 (I0.05) and 0.5 (I0.5) $\mu \mathrm{g} . \mathrm{L}^{-1}$, diuron at 0.05 (D0.05) and 0.5 (D0.5) $\mu \mathrm{g} . \mathrm{L}^{-1}$, S-metolachlor at 0.5 (S0.5) and 5 (S5) $\mu \mathrm{g} . \mathrm{L}^{-1}$ and their mixtures: M1 (I0.05+D0.05+S0.5) and M2 
(I0.5+D0.5+S5). The highest methanol concentration reached in the flasks (for treatment M2) was $0.0012 \%$. This concentration had already been shown not to be harmful to the two microalgal species (Dupraz et al., 2016). The same treatments were applied to the abiotic part of the experiments (without microalgae added to the flasks) as to the biotic component. Here, one replicate was made for each treatment with "culture medium" alone and two were made for each treatment with "culture medium + DOM".

During each experiment, samples were taken for biological and chemical analyses: the protocols are detailed in the following sections. The biological parameters monitored were: cell density (measured daily throughout the experiments), photosystem II effective quantum yield (measured on the last day) and relative intracellular lipid content (measured on the last day). The chemical parameters monitored were: nutrient concentrations, herbicide concentrations, dissolved organic carbon (DOC) concentrations and DOM optical properties, all of which were measured on the first and last days of each experiment.

\subsection{Biological endpoints}

\subsubsection{Measurements by flow cytometry}

Culture samples were analysed on an Accuri C6 flow cytometer (Becton Dickinson Accuri ${ }^{\mathrm{TM}}$ ) equipped with a blue (488 $\mathrm{nm})$ and a red $(640 \mathrm{~nm})$ laser, as described in Dupraz et al. (2016).

\subsubsection{Growth rate}

To measure the cell density, $300 \mu \mathrm{L}$ from all the cultures were sampled daily and fixed in glutaraldehyde (final concentration $0.25 \%$ ). Tubes were mixed and left for 15 minutes at room temperature in the dark before analysis. Cells were counted on a side scatter (SSC) versus FL3 (red fluorescence, $>670 \mathrm{~nm}$ ) cytogram for $C$. calcitrans and a FL1 (green fluorescence, 530/30 nm) versus FL4 (red fluorescence, 675/25 nm) cytogram for T. suecica (Dupraz et al., 2016). For each culture, the average growth rate $\left(\mu, \mathrm{h}^{-1}\right)$, corresponding to the slope of the regression line of $\ln \left(\right.$ cell. $\left.\mathrm{mL}^{-1}\right)$ on time $(\mathrm{h})$, was calculated.

\subsubsection{Relative intracellular lipid content}

The relative intracellular lipid content $\left(F L 1_{\text {Lipids }}\right.$ ) was estimated on the last day of the experiments using the green lipophilic fluorochrome BODIPY ${ }^{505 / 515}$ (Life Technologies ${ }^{\circledR}$, Carlsbad, CA, USA), following the protocol used by Dupraz et al. (2016). Briefly, for each culture, 200- $\mu \mathrm{L}$ samples were stained with a BODIPY $505 / 515$ working solution at $3 \mathrm{mg} . \mathrm{L}^{-1}$ for $C$. calcitrans and $4.8 \mathrm{mg} . \mathrm{L}^{-1}$ for $T$. suecica, leading to final BODIPY concentrations of $75 \mu \mathrm{g} . \mathrm{L}^{-1}$ (2.5\% DMSO) and $120 \mu \mathrm{g} . \mathrm{L}^{-1}$ (2.5\% DMSO), respectively. Stained samples were incubated at room temperature in the dark for 5 minutes for $C$. calcitrans and 6 minutes for T. suecica. FL1 values of cells (unstained cells and cells stained with BODIPY) were normalized using FL1 values of $2 \mu \mathrm{m}-$ fluorescent polystyrene microspheres (Flow Check ${ }^{\mathrm{TM}}$ High Intensity Alignment Grade Particles $2.00 \mu \mathrm{m}$, Polysciences Inc., Warrington, PA, USA), added to all samples prior to analysis. The normalization is resumed with the formula:

$F L 1_{\text {Lipids }}=\left(F L 1_{\text {stained microalgae }} / F L 1_{\text {stained microsphere }}\right) /\left(\mathrm{FL} 1_{\text {unstained microalgae }} / \mathrm{FL} 1_{\text {unstained microsphere }}\right)$

\subsubsection{Photosystem II effective quantum yield - Photosynthesis}

The PSII effective quantum yield (operational PSII quantum yield, $\Phi^{\prime}{ }_{\mathrm{M}}$ ) was measured on the last day of the experiments by Pulse-Amplitude Modulated (PAM) fluorescence using an Aquapen-C AP-C 100 fluorometer 
(Photon System Instruments ${ }^{\circledR}$, Drasov, Czech Republic). Measurements were made in 1-cm wide cuvettes using $2 \mathrm{~mL}$ of microalgal cultures diluted (1:2) in culture medium. Three $\Phi^{\prime}{ }_{\mathrm{M}}$ measurements were made for each culture, from which a mean was calculated.

\subsection{Chemical analyses}

Nutrient analyses were performed for all conditions and treatments. Pesticides were analysed in all control replicates (no pesticide added), including abiotic flasks, and in the highest concentrations tested (I0.5, D0.5, S5 and M2). DOM was characterized in all biotic and abiotic control replicates (no pesticides) and in the pesticide treatments that significantly impacted the microalgae.

Chemical analyses were performed on the first and last days of each experiment, on filtered samples. 55-mL samples were filtered using sterile filtration funnels containing a $0.45-\mu \mathrm{m}$ PES (polyethersulfone) filter (VWR, USA), previously rinsed with ultrapure water $(0.7 \mathrm{~L})$. On the first day of each experiment, one additional flask was prepared for each treatment in addition to the replicates in order to provide a sufficient volume for nutrient analyses and DOM characterization. This additional flask was immediately entirely sampled.

\subsubsection{Nutrient analyses}

For nitrate and orthophosphate analyses, $15 \mathrm{~mL}$ (out of $55 \mathrm{~mL}$ ) of the filtered culture samples were diluted 20fold with ultrapure water before injection. Analyses were performed by ionic chromatography with chemical suppression (COMPACT 881 IC Pro, Metrohm, Switzerland) equipped with a Metrohm 850 IC Conductivity Detector. The separation was performed with a Metrosep A Supp 4/5 Guard/4.0 pre-column followed by a Metrosep A sup 5 -250/4.0 anion exchange column. The eluent was a solution of $3.2 \mathrm{mM} \mathrm{Na}_{2} \mathrm{CO}_{3}$ and $1 \mathrm{mM}$ $\mathrm{NaHCO}_{3}$, and the chemical suppressor was a solution of $10 \mathrm{mM} \mathrm{H}_{2} \mathrm{SO}_{4}$. Quantification limits were $0.010 \mathrm{mg} . \mathrm{L}^{-1}$ for nitrates and $0.005 \mathrm{mg} . \mathrm{L}^{-1}$ for orthophosphates.

For silicate analysis, $20 \mathrm{~mL}$ were sampled from the additional flask of each treatment on the first day, and $5 \mathrm{~mL}$ per replicate of each treatment were pooled on the last day of experiments. Soluble silicate concentrations were determined by the colorimetric method with a Shimadzu UV-1800 spectrophotometer (Shimadzu Inc., Kyoto, Japan) according to the French standard NF T90-007 (AFNOR, 2001). The quantification limit was 0.05 mg.L-1. Silicates were only analysed in samples from the experiment with $C$. calcitrans.

\subsubsection{Pesticide analyses}

One hundred microlitres of filtered culture samples were diluted 10-fold using ultrapure water. $40 \mu \mathrm{L}$ of diluted samples were directly analysed by liquid chromatography (1290 Infinity system from Agilent Technologies, USA) coupled to a tandem mass spectrometer (6460 triple quadrupole LC/MS system from Agilent Technologies, USA) and after adding internal standards (irgarol-D9, diuron-D6, metolachlor-D6). The separation was performed using a Kinetex C18 column and a gradient of solvent A (solution of $5 \mathrm{mM}$ acetate ammonium and $0.1 \%$ acetic acid diluted in water ultrapure) and $\mathrm{B}$ (pure methanol) with a flow rate of $0.5 \mathrm{~mL} \cdot \mathrm{min}^{-1}$. Analyses of the three pesticides and their metabolites (only for diuron and S-metolachlor) were performed in MRM (multiple reactions monitoring) mode. Quantification limits were 0.24 ng.L $\mathrm{L}^{-1}$ for irgarol, $1.19 \mathrm{ng} . \mathrm{L}^{-1}$ for diuron, $4.43 \mathrm{ng} . \mathrm{L}^{-1}$ for DCPMU (1-(3,4-dichlorophenyl)-3-methylurea), $5.29 \mathrm{ng} . \mathrm{L}^{-1}$ for 1,2,4-DCPU (1-(2,4dichlorophenyl)urea), $4.26 \mathrm{ng} . \mathrm{L}^{-1}$ for 1,3,4-DCPU (1-(3,4-dichlorophenyl)urea), $1.11 \mathrm{ng} . \mathrm{L}^{-1}$ for S-metolachlor, $1.23 \mathrm{ng} . \mathrm{L}^{-1}$ for metolachlor OA ([(2-ethyl-6-methylphenyl)(1-methoxy-2-propanyl)amino](oxo)acetic acid) and 
3.13 ng.L $\mathrm{L}^{-1}$ for metolachlor ESA (2-[(2-ethyl-6-methylphenyl) (2-methoxy-1-methylethyl)amino]-2-oxoethanesulfonic acid).

\subsubsection{DOM characterization}

After filtration at $0.45 \mu \mathrm{m}$, all experimental samples were stored at $4{ }^{\circ} \mathrm{C}$ in the dark until DOM analyses. To characterize DOM evolution over time in the control cultures and cultures exposed to I0.5 and M2, DOC concentrations were determined and optical analyses (absorbance and fluorescence) were performed. In order to compare the evolution of each parameter over time between the different conditions (with and without DOM), results were expressed as the difference between the first and last days of the experiments (value last day $_{-}$value $_{\text {first }}$ day).

\subsubsection{Dissolved organic carbon (DOC)}

DOC concentrations were determined using a Total Organic Carbon analyzer (Shimadzu TOC-V CSN, Japan), calibrated with solutions of potassium hydrogen phthalate $\left(\mathrm{C}_{6} \mathrm{H}_{4}(\mathrm{COOK})(\mathrm{COOH})\right)$ and run in non purgeable organic carbon (NPOC) mode. Ten millilitres of filtered culture samples were acidified with 2 M hydrochloric acid then sparged for 6 minutes with high purity (5.0) synthetic air (LINDE, France). The DOC concentration result is the mean of the three to four injections that were the most satisfactory in terms of variation coefficient $(<2 \%)$. At least two certified reference waters (Environment Canada purchased by ANALAB, France) were systematically analysed within each sample series in order to validate DOC measurements. Results of concentration variations during the experiment were expressed per microalgal cell.

\subsubsection{Absorbance analyses}

Four-millilitre samples of filtered cultures were used for absorbance measurements performed on a Jasco V-560 spectrophotometer (JASCO, France) equipped with deuterium and tungsten iodine lamps. Samples were placed in a 1-cm path length fused silica cell (Hellma). The light absorbing properties of DOM were studied via two optical indices: the Specific UV Absorbance $\left(\mathrm{SUVA}_{254}\right)$ and the spectral Slope Ratio $\left(\mathrm{S}_{\mathrm{R}}\right)$. The $\mathrm{SUVA}_{254}$ (L.mg.C $\mathrm{C}^{-1} \cdot \mathrm{m}^{-1}$ ) index provides information on the aromatic character of DOM (Weishaar et al., 2003); it is calculated as the ratio between UV absorbance at $254 \mathrm{~nm}$ and DOC concentration $\left(\mathrm{mg} . \mathrm{L}^{-1}\right)$. The $\mathrm{S}_{\mathrm{R}}$ parameter, used as a proxy for molecular weight variation, corresponds to the ratio between the spectral slopes of the 275$295 \mathrm{~nm}$ region and the 350-400 $\mathrm{nm}$ region of the absorbance spectrum (Helms et al., 2008).

\subsubsection{EEM spectroscopy analyses}

Four-millilitre samples of filtered cultures were used, after absorbance, for fluorescence measurement. The EEM spectra were recorded using a Fluorolog FL3-22 fluorometer (Horiba Jobin Yvon, France) equipped with a xenon lamp $(450 \mathrm{~W})$ and a double monochromator at both excitation and the emission sides. Samples were contained in a $1-\mathrm{cm}$ path length quartz cuvette (Hellma), thermostated at $20^{\circ} \mathrm{C}$. The EEM spectra were composed of seventeen emission spectra acquired from 260 to $700 \mathrm{~nm}$ (with an increment of $1 \mathrm{~nm}$ and an integration time of 0.5 seconds) with excitation wavelengths in the range of 250 to $410 \mathrm{~nm}$ (with an increment of $10 \mathrm{~nm}$ ). Each spectrum obtained was corrected by subtracting an ultrapure water blank spectrum to eliminate water Rayleigh and Raman scattering peaks. Spectra were also corrected instrumentally as previously detailed in Huguet et al. (2009b). EEM spectra allowed the characterization of DOM and its evolution during the experiments. Two 
fluorescence parameters were more particularly monitored in this work: HIX (or humification index) and BIX (or biological index). The HIX index, used to characterize DOM humification and related to aromaticity (Zsolnay et al., 1999), was calculated as the ratio of the area from emission wavelength 435 to $480 \mathrm{~nm}$ divided by the area from emission wavelength 300 to $345 \mathrm{~nm}$ for an excitation wavelength of $250 \mathrm{~nm}$. The BIX index (Huguet et al., 2009b) is an indicator of recent autochthonous production of DOM; it was calculated as the ratio of emission intensity at $380 \mathrm{~nm}$ to emission intensity at $430 \mathrm{~nm}$ for an excitation wavelength of $310 \mathrm{~nm}$.

\subsection{Statistical analyses}

For each experiment, one-way ANOVAs were performed separately on each condition (with and without DOM) to detect significant differences in growth rate, FL1 Lipids ratio and photosynthetic efficiency between control and herbicide-exposed cultures (with a p-value $<0.05$ considered as statistically significant). When significant differences were detected, a Tukey post-hoc test was performed.

Evolution of nutrient and pesticide concentrations over time were assessed with Student's t-test or Welch's t-test (with a p-value <0.05 considered as statistically significant) after having checked the homoscedasticity with Fisher's F-test. The DOM characterization results of herbicide-exposed conditions were compared to control conditions with the same statistical tests used for nutrients and pesticides.

When the result was not significant but the data suggested a trend, the type II error $\beta$ was calculated, corresponding to the probability of wrongly accepting the null hypothesis.

Principal components analyses (PCA) were performed to illustrate the relationships between biological and chemical endpoints characterizing DOM evolution in the controls and the herbicide treatments with the greatest biological effects in conditions with and without DOM. These analyses, done on parameters statistically affected by treatments with herbicides, were performed using the R package FactoMineR (Lê et al., 2008).

All statistical analyses were performed with R 3.2.2. (Ihaka and Gentleman, 1996) and all graphs were drawn with SigmaPlot ${ }^{\circledR} 12.0$ software (Systat Software Inc., USA).

\section{Results}

\subsection{Herbicide concentrations}

Chemical analysis of the concentrated DOM sample showed no evidence of irgarol or diuron and its metabolites, but did show the presence of S-metolachlor: a concentration of $9.7 \mathrm{ng} . \mathrm{L}^{-1}$ in the extract, corresponding to 1.94 ng. $\mathrm{L}^{-1}$ in the "culture medium + DOM" flasks. S-metolachlor metabolites were also quantified in the DOM extract: 793 ng. $\mathrm{L}^{-1}$ for ESA and 393 ng.L. $\mathrm{L}^{-1}$ for OA, corresponding to expected concentrations around $160 \mathrm{ng} . \mathrm{L}^{-1}$ and 80 ng. $\mathrm{L}^{-1}$, respectively, in the "culture medium + DOM" flasks.

On the first day of the experiments, irgarol, diuron and S-metolachlor were not found in the controls (biotic or abiotic, data not shown), but ESA and OA metabolites were detected in all treatments containing DOM (around $150 \mathrm{ng} . \mathrm{L}^{-1}$ for ESA and $127 \mathrm{ng} . \mathrm{L}^{-1}$ for OA, data not shown). In abiotic treatments, with and without DOM, the measured concentrations of the three herbicides, singly and mixed, were in the same range in the highest pesticide treatments: between 480 and $565 \mathrm{ng} . \mathrm{L}^{-1}$ for irgarol (Figure 1A), compared with the theoretical concentration of 500 ng.L $\mathrm{L}^{-1}$; between 515 and 645 ng. $\mathrm{L}^{-1}$ for diuron (Figure 1B), slightly above the theoretical concentration of $500 \mathrm{ng} . \mathrm{L}^{-1}$; and between 4680 and $4930 \mathrm{ng} . \mathrm{L}^{-1}$ for S-metolachlor (Figure 1C), close to the theoretical concentration of $5000 \mathrm{ng} . \mathrm{L}^{-1}$. In the flasks containing microalgae, the measured concentrations of the 
three herbicides at day 0 were significantly lower than concentrations in the abiotic flasks. Irgarol concentrations were between 240 and 290 ng.L. $\mathrm{L}^{-1}$ in I0.5 and M2 of both conditions for C. calcitrans (Figure 1A). For T. suecica cultures without DOM, irgarol concentrations were $116 \pm 2 \mathrm{ng} . \mathrm{L}^{-1}$ in I0.5 and $212 \pm 1 \mathrm{ng} . \mathrm{L}^{-1} \mathrm{in} \mathrm{M} 2$, and around 183 ng.L $\mathrm{L}^{-1}$ with DOM. For diuron, concentrations were quite similar and ranged from 320 to 430 ng.L.- for the two species in both treatments, with and without DOM (Figure 1B). No diuron metabolites were detected at day 0. S-metolachlor concentrations were similar with and without DOM for S5 and M2: around 3000 ng.L $\mathrm{L}^{-1}$ for $C$. calcitrans and $2260 \mathrm{ng} . \mathrm{L}^{-1}$ for T. suecica. ESA and OA metabolites were detected in cultures where DOM was added, at concentrations in the same range as for controls (around 155 ng.L.-1 for ESA and 130 ng.L $\mathrm{L}^{-1}$ for OA, data not shown) and remained similar until the end of the experiment.

A significant decrease in the concentrations of the three herbicides was observed over time in the abiotic component without DOM: around $-37 \%$ for irgarol, $-25 \%$ for diuron and $-15 \%$ for S-metolachlor in treatments with single molecules. In the abiotic component with DOM, whereas a decrease of $-22 \%$ over time was observed for irgarol singly and in mixture, no significant difference was observed for diuron and S-metolachlor between the first and last days. In flasks containing microalgae, no concentration variations over time were observed for irgarol except in I0.5 with $C$. calcitrans cultures containing DOM (-49\%). Diuron concentrations did not significantly evolve over time with $C$. calcitrans cultures with or without DOM, while for T. suecica, a decrease around $-59 \%$ was observed in D0.5 only, both with and without DOM, but not in mixture. No diuron metabolites were detected at the end of the experiments. Finally, for both species no decline in S-metolachlor concentration was observed over time in S5 but a significant increase of the concentration was shown during the experiment for M2 (concentration at the end of experiments was around $4270 \mathrm{ng} . \mathrm{L}^{-1}$ ). No S-metolachlor metabolites were detected over the experiment in abiotic or biotic components without DOM.

\subsection{Nutrients}

On the first day of the experiments, nutrient concentrations in conditions with and without DOM were in the same range: around $60 \mathrm{mg} . \mathrm{L}^{-1}$ nitrates, $1.6 \mathrm{mg} . \mathrm{L}^{-1}$ orthophosphates and $22 \mathrm{mg} . \mathrm{L}^{-1}$ silicates (Figure 2). Due to conservation problems, no orthophosphate data are available for T. suecica.

Nutrient concentrations were similar and stable over time in the abiotic component (data not shown). In $C$. calcitrans cultures at the end of experiment, nitrate (Figure 2A) and orthophosphate (Figure 2B) concentrations decreased more in the control flasks with DOM addition than without it. In $C$. calcitrans cultures exposed to pesticides without DOM, no significant difference was detected between controls and herbicide-exposed cultures at the end of the experiment. In cultures with DOM, nitrate decrease over time was the same as in the controls, except for I0.05 (-26\% vs. $-42 \%$ in controls compared with the first day), I0.5 and M2 (where no decrease was observed over time). For orthophosphates, no significant difference from controls was observed without DOM. With DOM, orthophosphates were almost entirely consumed, except for I0.5 and M2 (no variation over time). For the silicates, the decrease was similar between controls with and without DOM (around 50\%) (Figure 2C). In the condition without DOM, this decrease seemed lower under pesticide exposure, especially for I0.5 and M2, compared to the controls. With DOM addition, no difference with controls was observed after 7 days (-63\% vs. $50 \%$ for controls), except for M2, where no decrease occurred over the experiment.

In $T$. suecica cultures, a striking decrease in nitrates of at least $80 \%$ was observed over time in almost all treatments, except in I0.5, D0.5 and M2 (Figure 2D). 


\subsection{Pesticide effects on microalgae}

\subsubsection{Pesticide effects without DOM addition}

Among the concentrations and mixtures tested, only I0.5 and M2 had significant effects on all physiological parameters studied on C. calcitrans and these were similar: inhibition of growth rate (about -56\%; growth curves are available in the supplementary material, S1), decrease in the ratio of relative lipid content $(-50 \%)$, and inhibition of photosynthetic efficiency (-28\%) (Figure 3A). Smaller effects were also observed on growth rate and relative lipid content ratio in cultures exposed to I0.05. Likewise, for T. suecica (Figure 3B, growth curves are available in the supplementary material, S2), I0.5 and M2 treatments showed significant decreases for $\mu$ ($56 \%$ and $-63 \%$, respectively), FL1 Lipids ratio (-32\% and $-26 \%$, respectively) and $\Phi^{\prime}{ }_{M}(-22$ and $-28 \%$, respectively).

\subsubsection{Pesticide effects with natural DOM addition}

DOM addition to the control cultures of $C$. calcitrans significantly increased $\mu(+9.6 \pm 0.5 \%)$ and decreased FL1 Lipids ratio $(-38.6 \pm 1.8 \%)$, compared with the controls without DOM (Table 1; growth curves are given in the supplementary material S1). For T. suecica, no significant effects were detected (Table 1; growth curves are given in the supplementary material S2). Exposure to I0.5 or to mixture M2 with DOM significantly inhibited the growth rate of $C$. calcitrans by about $51 \%$ (Figure 3A). FL1 Lipids ratio decreased with I0.5 and M2 (around $27 \%$ for each); $\Phi^{\prime}{ }_{\mathrm{M}}$ was significantly affected in the I0.5 treatment $(-24.1 \pm 0.4 \%)$ and $\mathrm{M} 2(-27.3 \pm 0.8 \%)$. For $T$. suecica with DOM, $\mu$ and FL1 $1_{\text {Lipids }}$ ratio decreased significantly with the highest concentrations of diuron, irgarol and mixture M2: -9 to $-75 \%$ for growth rate, -10 to $-18 \%$ for $F L 1_{L i p i d s}$ ratio and -25 to $-35 \%$ for $\Phi^{\prime}{ }_{M}$, the strongest effects being due to M2, except for lipids (Figure 3B).

\subsection{DOM characterization in the treatments with the strongest effects on microalgae}

For both microalgal species, the treatments that induced significant inhibition of the three biological parameters studied (I0.5 and M2), were selected for DOM characterization.

First, the change in DOC concentration was measured over the experiments. In C. calcitrans (Figure 4A) and T. suecica controls (Figure 4B) with and without DOM, $\triangle \mathrm{DOC}$ concentration per algal cell increased in the same way over the experiments. Under pesticide exposure without DOM, $\triangle \mathrm{DOC}$ was only significantly higher than in

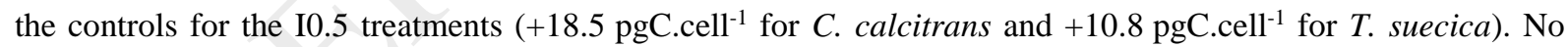
such significant increase was demonstrated with DOM addition in C. calcitrans exposed to I0.5 or M2. For T. suecica, $\triangle \mathrm{DOC}$ was not statistically different from the controls for I0.5 exposure with DOM, whereas a high and significant increase of $\triangle \mathrm{DOC}$ concentration per cell was measured for $\mathrm{M} 2$ exposure $\left(+31.8 \mathrm{ngC}\right.$.cell $\left.{ }^{-1}\right)$.

The SUVA 254 index decreased between the first and last day of the experiments in all cultures (controls and I0.5 and M2 exposures) for both microalgal species (Figure 4C and D). With or without DOM, pesticide exposure did not significantly impact $\triangle \mathrm{SUVA}_{254}$ in $C$. calcitrans cultures. In $T$. suecica cultures without DOM and exposed to I0.5 and M2, $\triangle \mathrm{SUVA}_{254}$ was significantly reduced (to about $-2.24 \mathrm{~L} \cdot \mathrm{mgC}^{-1} \cdot \mathrm{m}^{-1}$ while the mean control result was $\left.-2.55 \pm 0.03 \mathrm{~L} \cdot \mathrm{mgC}^{-1} \cdot \mathrm{m}^{-1}\right)$. No significant difference was observed in $\Delta \mathrm{SUVA}_{254}$ between herbicide-exposed cultures and controls when DOM was added. 
The $S_{R}$ index increased over the experiment in all treatments for both species (Figure 4E and F). Without DOM, $\Delta \mathrm{S}_{\mathrm{R}}$ increase with irgarol exposure (I0.5) was significantly lower than the control for both species: $-81 \%$ for $C$. calcitrans and $-88 \%$ for $T$. suecica; no significant difference was observed between control and M2, although a similar trend can be suspected ( $\beta$ risk $=0.74$ and 0.49 for $C$. calcitrans and $T$. suecica, respectively). With DOM addition, $\mathrm{S}_{\mathrm{R}}$ only differed significantly for $C$. calcitrans under $\mathrm{M} 2$ exposure.

The HIX index (humification index) decreased during the experiments in all treatments without DOM, and no significant difference was observed between control and pesticide-exposed cultures (high $\beta$ errors for M2 treatments: 0.81 for $C$. calcitrans and 0.86 for $T$. suecica; Table 2). With DOM in the cultures, this index also decreased in the controls over time for both species, while it increased significantly (positive $\Delta \mathrm{HIX}$ values) in $C$. calcitrans cultures exposed to M2 and in T. suecica exposed to I0.5 and M2. Finally, BIX index (biological index) increased for all C. calcitrans treatments with and without DOM, with no difference between controls and pesticide-exposed cultures, while no variation occurred over time in $T$. suecica cultures, whatever the condition and treatment.

\subsection{Relationships between biological and chemical parameters in the treatments with the strongest effects on microalgae}

Principal component analyses (PCA), illustrating the relationships between biological and chemical parameters, showed that the first two axes explained around $80 \%$ of the total variance for $C$. calcitrans (Figure 5A and B) and T. suecica (Figure 5C and D), respectively. The first axis explained most of the total variance for both species. It expressed the influence of herbicide treatments (Figure 5B and D), as demonstrated by the control cultures grouped on the right-hand side, discriminated from the exposed cultures by a high growth rate that was positively correlated with high photosynthetic efficiency and $\Delta \mathrm{S}_{\mathrm{R}}$ index for both species (Figure 5A and C). On the left side, cultures exposed to irgarol (I0.5) or to mixture 2 (M2) were opposite to these parameters. Growth rate, photosynthetic efficiency and $\Delta \mathrm{S}_{\mathrm{R}}$ index were negatively correlated with $\triangle \mathrm{DOC}$ for the two species and in addition to $\triangle \mathrm{SUVA}_{254}$ for $T$. suecica.

The second axis, on which $\Delta$ HIX (uncorrelated with any biological parameter for either species) seemed to be better represented, allowed to slightly discriminate the conditions with and without DOM for T. suecica (Figure 5D), contrary to $C$. calcitrans for which no differentiation could be made.

\section{Discussion}

The aim of this study was to investigate the influence of natural DOM on the toxicity of three herbicides: irgarol, diuron and S-metolachlor, singly and in mixtures, to two marine microalgae, Chaetoceros calcitrans and Tetraselmis suecica, in non-axenic conditions. The effects were assessed on growth, intracellular lipid content and operational photosynthetic yield. In parallel, chemical parameters were also monitored to characterize pesticide exposure and DOM.

\subsection{Pesticide concentrations}

Pesticide analyses on concentrated DOM, which showed the absence of irgarol and diuron (and its metabolites) and the presence of S-metolachlor and its metabolites (ESA and OA), were in accordance with results of parentmolecule analyses made on water samples (before the concentration and desalination), where only S-metolachlor was found $\left(2.8 \mathrm{ng} . \mathrm{L}^{-1}\right)$. These results also agree with those in the literature, which showed that the chemical 
footprint in Arcachon Bay was dominated by S-metolachlor and its metabolites due to the agricultural practices on the watershed (Dagens, 2012; REPAR, 2015; Tapie et al., 2016). However, due to previously reported occurrence of various other molecules in the sampling area (such as acetochlor, not analysed in this study; REPAR, 2015), we cannot exclude their presence in our concentrated DOM sample.

In our experimentation, pesticide analyses were performed on samples from maximal concentration treatments on the first and last days of the experiments. Results showed that measured concentrations were in accordance with nominal ones in abiotic experiments with and without DOM. However, concentrations measured in flasks containing microalgae and their associated bacteria both with and without DOM were lower than expected: around $-38 \%$ for diuron, $-46 \%$ for S-metolachlor, and $-50 \%$ (C. calcitrans) to $-67 \%$ (T. suecica) for irgarol relative to the concentrations in the abiotic experiments. Two hypotheses could explain these results: an almost instantaneous adsorption of the molecules to the cell walls of microalgae and bacteria and/or a very fast internalization into cells. Indeed, these three substances have high $\log \mathrm{K}_{\mathrm{ow}}: 2.9$ for diuron, 3.4 for S-metolachlor and 4.0 for irgarol (Belles, 2012; Tetko et al., 2005). This parameter, namely the octanol/water partition coefficient, is the measurement of differential solubility of a given molecule in octanol and water. Cell walls are composed of lipids (phospholipids, lipoproteins and free fatty acids), the polarity of which is similar to octanol. For this reason, $\log \mathrm{K}_{\mathrm{ow}}$ is used to assess the lipophilic character (affinity with cell walls) of molecules (Amiard, 2011). Based on their $\log \mathrm{K}_{\mathrm{ow}}$, the three molecules studied can be considered as nonpolar, lipophilic and bioaccumulative. The cell-wall affinity of these three molecules can thus be ranked as follows: diuron $<\mathrm{S}$ metolachlor < irgarol and seems to correspond well with the differences observed between abiotic and biotic flasks. The variation observed for irgarol between the two species can be explained by the differing composition of the microalgal cell walls. Indeed, the cell wall of the chlorophyte $T$. suecica has a smooth surface rich in lipids in direct contact with the environment (Chrétiennot-Dinet, 1990), suggesting a higher affinity of irgarol for these cells. This contrasts with $C$. calcitrans, which is a diatom with a cell wall (namely a frustule) essentially composed of silicate and covered in an organic coating (Round et al., 2007; Tesson and Hildebrand, 2013) for which irgarol would have a lower affinity. This adsorption to the cells could also be combined with a fast internalization of the molecules into them. Indeed, Nestler et al. (2012) showed that an inhibition of $\Phi_{\text {PSII }}$ took place only 1-2 minutes after addition of diuron to Chlamydomonas reinhardtii cultures, suggesting a very rapid internalization of the molecule. Given the lapse of time between the addition of herbicides to the cultures, sampling and filtration (up to 2-3 hours), we can hypothesize that molecules of diuron could have been, at least partly, internalized already. No quantitative estimate of loss due to this phenomenon can be given, but Chaumet et al. (2016) showed that the equilibrium between diuron concentrations internalized into cells (in biofilms) and in the water can be reached within 2 hours. For the two other molecules, there are no data available in the literature to support this hypothesis of very fast internalization. The variation observed for irgarol could also partly be due to the presence of bacterial communities naturally associated with $T$. suecica and $C$. calcitrans cultures, which could be different as demonstrated by Nicolas et al. (2004). To verify these hypotheses, it would be necessary to do (i) similar experiments including axenic conditions and non-axenic conditions, (ii) additional analyses of bacterial composition (isolation and identification by phylogenetic analysis based on 16S rDNA; Nicolas et al., 2004). 
At the end of the experiments, losses over time were observed for all molecules in the abiotic component without DOM, which could be due to adsorption of compounds to the walls of the borosilicate glass flasks and/or to their volatilization in the headspace of the flasks. In the abiotic component with DOM, no variations were observed for diuron and S-metolachlor concentrations compared with initial concentrations. The pesticide analyses were performed on the total dissolved fraction, including the part of the pesticides possibly adsorbed to DOM. Given the results, it seemed therefore that pesticides and DOM were associated in some way, which prevented their adsorption to glass walls (higher affinity of pesticides for DOM components) or their volatilization. Losses of irgarol over time were also observed with DOM, although to a lesser extent than without DOM (-21\% with DOM vs. $-36 \%$ without DOM). In the same way, interaction with DOM could have occurred and probably limited adsorption and volatilization, although less efficiently than for diuron and S-metolachlor. As no metabolites were found at the end of experiments for the latter (apart from S-metolachlor metabolites from the natural DOM), the losses were probably also due to an abiotic degradation of parent compounds (photodegradation and/or hydrolysis). As for irgarol, although metabolites were not analysed, its decrease with DOM could result from a photodegradation of the molecule: several studies have shown that irgarol degradation under sunlight was more rapid than that of diuron (Okamura, 2002) and was catalysed/promoted by humic-type substances (= photosensitizer; Okamura and Sugiyama, 2004; Sakkas et al., 2002).

In the biotic flasks, decreases in diuron concentrations over the experiments were only measured in the D0.5 treatment applied to $T$. suecica in conditions with and without DOM. Diuron losses were not due to biodegradation (metabolites not detected) or photodegradation (the decrease was only observed for the single molecule with this species). Diuron molecules were thus probably on or inside the microalgal and bacterial cells, corresponding to the continuation of the adsorption/internalization phenomenon already noticed on the first day, and amplified with the growing number of cells. This decrease was not shown in T. suecica cultures exposed to M2 and it can be hypothesized that diuron molecules in mixture M2 would be less bioavailable for microalgal cells, or outcompeted by the other herbicides for adsorption. Alternatively, the strong growth inhibition induced by mixture M2 prevented the continuation of the adsorption/internalization phenomenon observed from the first day. No such diuron decrease over time was observed in $C$. calcitrans cultures, perhaps due to a lower affinity for the diatom frustule (and/or its organic coating; Round et al., 2007; Tesson and Hildebrand, 2013) leading to an adsorption equilibrium being reached from the beginning of experiment. DOM did not exert any influence on diuron concentrations in the cultures.

As for irgarol, decrease was only shown in I0.5 treatment with DOM in C. calcitrans cultures. Irgarol metabolites were not analysed, consequently it cannot be excluded that a degradation (by bacteria and/or microalgae) of irgarol occurred over the experiment, possibly promoted by DOM. Another hypothesis would be an interaction between irgarol and DOM in the I0.5 treatment, favouring an adsorption/internalization, together with a lowered toxicity due to changes in irgarol bioavailability. In this case, DOM would play a protective role against irgarol toxicity. Surprisingly, no such decrease was observed in mixture M2, but in this case the other herbicides could have competed with irgarol for complexation with DOM and/or adsorption. However, there are no data available in the literature to validate or refute these hypotheses.

Finally, whereas no variation of S-metolachlor concentrations was observed in the single molecule treatments for either species, with or without DOM, an increase of concentration over time was seen in all mixture treatments, 
reaching $+57 \%$ of the $\mathrm{S}$-metolachlor concentration added at day 0 in the flasks (a concentration similar to the abiotic flasks). As shown by the results from day 0 compared to the abiotic flasks, a fast adsorption/internalization of S-metolachlor occurred in the cultures of both species. In treatment S5, where there was no growth impairment, concentrations did not change significantly over the experiment. However when growth was strongly inhibited in treatment M2, the increased concentration probably indicates desorption from cell walls, independently from DOM addition. It can be supposed that irgarol effects induced changes in structure, composition or permeability of cell walls that would have diminished S-metolachlor affinity.

\subsection{Herbicide toxicity without natural DOM addition}

For all cultures, nutrient analyses performed on the first and last days of experiments showed that nitrates, orthophosphates and silicates were not limiting for algal growth. When a strong growth inhibition occurred, as with treatments I0.5 and M2, no variation was observed over time in nitrate or orthophosphate concentrations, meaning that, as expected, there was almost no consumption.

Exposure to $0.5 \mu \mathrm{g} . \mathrm{L}^{-1}$ irgarol was highly toxic to the two species compared with diuron, which induced almost no effects at the same concentration, as already reported by Dupraz et al. (2016).

This stronger toxicity of irgarol towards microalgae has also been shown in other studies (Devilla et al., 2005; Gatidou and Thomaidis, 2007), although these two herbicides share the same metabolic target (protein D1 of the photosystem II). The difference is likely due to a higher hydrophobicity of irgarol compared with diuron (allowing it to cross cell membranes more easily) and to a higher affinity of irgarol for the $\mathrm{Q}_{\text {в }}$ niche on the D1 protein (Chesworth et al., 2004). Given that no significant effects were detected with treatments D0.5 or S5, the effects observed on C. calcitrans after exposure to mixture M2, which was similar to I0.5, can thus probably be attributed to irgarol. For T. suecica, toxic effects were slightly greater on growth and photosynthesis with treatment M2 than with I0.5: growth $-63 \pm 1 \%$ vs. $-56 \pm 1 \%$ and photosynthesis $-28 \pm 0 \%$ vs. $-22 \pm 0 \%$, respectively. This could possibly be due to an interaction between herbicides that increased the toxicity, as already observed with diuron and irgarol by Koutsaftis and Aoyama (2006). However, this hypothesis remains to be demonstrated by specific experiments devoted to studying mixtures (Cedergreen et al., 2007). Despite the sublethal effects previously detected by Roubeix et al. (2011) such as deformed frustules in the freshwater diatom Surirella angusta after exposure to $5 \mu \mathrm{g} . \mathrm{L}^{-1} \mathrm{~S}$-metolachlor (20\%o for exposed cells vs. around $0 \%$ for controls) and by Coquillé et al. (2015) on the linearity of movements for the freshwater diatom Gomphonema gracile after exposure to $1 \mu \mathrm{g} . \mathrm{L}^{-1} \mathrm{~S}$-metolachlor (increase of linearity compared with controls), no effects of Smetolachlor were shown in the present study, even on the relative lipid content. Indeed, because the mode of action targets elongases involved in the synthesis of fatty acids and lipids, an effect of this kind might be expected (Fuerst, 1987). Our results, which are in agreement with the literature (Juneau et al., 2001; Ma et al., 2006; Thakkar et al., 2013), show no toxicity at these environmental concentrations.

In addition to the severe physiological effects of I0.5 and mixture M2, other effects on microalgae were also deduced from analyses of autochthonous DOM produced in the cultures where no natural DOM was added. Indeed, the increase in dissolved carbon per cell in the culture medium over time, was higher for I0.5 than for the controls: $+370 \pm 40 \%$ for $T$. suecica and around $+4000 \pm 900 \%$ for C. calcitrans. It is generally accepted that such extracellular DOC increase in microalgal cultures is linked to either cell excretion or cell death (Findlay and Sinsabaugh, 2003). In the present study, analysis of cultures by flow cytometry indicated very slow growth 
rather than cell death (a single population showing very well grouped cells, data not shown). This increase of DOC can thus be linked to excretion of microalgal cells and their associated bacteria. Bacteria play a key role in algal growth and survival in culture and, reciprocally, the algae contribute to bacterial development (Amin et al., 2015; Kim et al., 2014; Ramanan et al., 2016; Windler et al., 2014). Bacteria contribute to the bioavailability of various compounds such as vitamins (necessary for the development of microalgae), which some species are unable to synthesize (Croft et al., 2005; Croft et al., 2006; Droop, 2007). Based on $\triangle$ SUVA $_{254}$ results, the DOC increase was not accompanied by a modification of aromaticity for C. calcitrans, as these were no different to the controls. For T. suecica, however, decrease of $\Delta \mathrm{SUVA}_{254}$ was lower in I0.5 and M2 exposed cells. Here the microalgae and their associated bacteria might have (i) secreted/excreted more aromatic molecules than controls; and/or (ii) secreted/excreted less non-aromatic molecules than controls; (iii) secreted/excreted molecules that were more easily transformed by chemical reaction (e.g. condensation, polymerization) and/or by the bacteria, thus forming more aromatic molecules. In the three cases, the differential excretion or secretion between controls and herbicide-exposed cultures could reflect stress effects. Indeed, several studies have shown that the composition of excreted substances (protein, lipids or sugars) can vary depending on microalgal species, growth phase and physico-chemical conditions (de Brouwer et al., 2003; Hellebust, 1965; Urbani et al., 2012; Zhang et al., 2016a) including metal contaminations (Herzi, 2013; Taylor et al., 2016). In the case of T. suecica exposed to I0.5 and M2, this enhanced excretion associated with very low growth remains to be explained, but could result from ageing of cells between each doubling, detoxification mechanisms and/or cell impairment.

Neither the results on autochthonous DOM production index BIX, nor those of HIX, related to humification/aromaticity, showed differences between treatments for either species. Control and exposed cells probably excreted similar quantities and types of fluorescent molecules and/or underwent processes such as polymerization, polycondensation or polyaddition leading to the formation of similar fluorescent molecules. The increase in $\mathrm{S}_{\mathrm{R}}$ (inversely correlated with average molecular weight) in control cultures of both species during the experiments reflected a decrease in molecular weight of molecules present in autochthonous DOM. In the I0.5 treatment for both species, $S_{R}$ also increased over time but significantly less than in the controls, suggesting that the types of molecules excreted were different. These variations in excretion by microalgal cells exposed to pesticides were also observed by Bester et al. (1995). In this previous study, which is to our knowledge the only one on the subject to date, the authors obtained a positive correlation between the increase of amino acid excretion, dissolved organic phosphorus and nitrogen concentrations, and the increase of atrazine concentration in mesocosms containing four species of marine diatoms (Thalassiosira punctigera, Thalassiosira rotula, Nitzschia pungens and Skeletonema costatum) and one prymnesiophyte (Phaeocystis globosa). At the same time, they observed a decrease of primary production during the growth phase. They hypothesized that this increase in excretion was linked to stress exerted by the atrazine, resulting either in cell wall damage (causing losses) or cell lysis. In the present study, as this latter hypothesis was excluded, the differential excretion (quantity and quality) of cells could potentially be linked to stress caused by the irgarol and perhaps also to a modified degradation of DOM by bacteria. However, to pinpoint a possible reason for this excretion, analyses would be necessary on the composition of the excreted substances and cell wall, cell mechanisms (metabolic waste, detoxification of cells, cell damage, etc..) and the relative contribution of bacteria to these changes. 


\subsection{Modulation of herbicide toxicity in the presence of natural DOM}

DOM addition to the culture media on the first day of experiments did not modify nutrient concentrations (nitrates, orthophosphates or silicates) in the cultures. Similarly to the conditions without DOM, the absence of variation or a lower consumption of nutrients over time was observed in treatments where algal growth was inhibited.

DOM addition to the cultures boosted C. calcitrans growth ( $+10 \%$ for average growth rate in controls) while no significant effect was shown on $T$. suecica average growth rate, although final cellular concentration was significantly enhanced with DOM: $751,500 \pm 25,500$ cell. $\mathrm{mL}^{-1}$ vs. $660,500 \pm 20,700$ cell. $\mathrm{mL}^{-1}$ respectively (Figure S1 and S2 in supplementary material). Therefore, it can be hypothesized that microalgae used/consumed molecules resulting from bacterial metabolism on DOM, as the cultures were non-axenic or ii) used molecules directly from the natural DOM. Indeed, bacteria release extracellular enzymes (hydrolases such as proteases, polysaccharidases and glucosidases), which hydrolyse polymeric matter (Nagata, 2008). This hydrolysis releases inorganic and organic compounds such as vitamins (B12, B1 or B7) that some microalgal species are unable to synthesize (Croft et al., 2005, 2006; Droop, 2007). Several other studies have also shown the ability of microalgae in axenic conditions to use organic molecules such as sugars (e.g. glucose; Liu et al., 2009), acetate (Laliberté and de la Noüe, 1993), or humic substances (Campbell et al., 1997; Millour, 2011; Vigneault, 2000), which are components of natural DOM (Benner, 2003; Kujawinski, 2011). In order to provide further insights on the quantity and type of molecules available and consumed by microalgae, experiments in axenic environment (without bacteria) would be needed, as would more in-depth analyses of DOM composition at the beginning and end of experiments.

With DOM addition, biological results of herbicide-exposed cultures showed, for $C$. calcitrans, a slight but significant decrease of the effect induced by $\mathrm{I} 0.5$ and $\mathrm{M} 2$ on growth rate and FL1 Lipids ratio compared to results without DOM. For T. suecica, however, DOM addition exacerbated the toxicity of pesticides: in D0.5 where no effect was found on growth rate or FL1 Lipids ratio without DOM, an inhibition of around $-10 \%$ for both parameters appeared with natural DOM addition. For I0.5 and M2, DOM addition resulted in a more pronounced toxic effect on growth rate and photosynthetic efficiency. These variations of herbicide toxicity with and without DOM were not due to differences in exposure concentrations, as these were similar. In the same way, the presence of metolachlor metabolites (around $150 \mathrm{ng} . \mathrm{L}^{-1}$ metolachlor ESA and $127 \mathrm{ng} . \mathrm{L}^{-1}$ metolachlor OA) with DOM cannot explain such variations. Indeed, additional tests performed with metolachlor ESA and OA at concentrations up to $500 \mu \mathrm{g} . \mathrm{L}^{-1}$ showed no toxic effect on the growth of these two microalgal species (personal communication). The absence of toxicity of both metabolites at a very high concentration (75 mg.L $\left.\mathrm{L}^{-1}\right)$ towards Nitzschia nana has already been reported by Roubeix et al. (2012). Changes in toxicity of organic chemicals towards microalgae induced by organic matter were also observed by Zhang et al. (2016b), who are to our knowledge the only authors who published a study combining microalgae, natural organic matter and contaminants. These authors showed that the presence of natural organic matter from Suwannee River (IHSS) increased acute toxicity of monochlorobenzene and 1,2-dichlorobenzene, while it decreased toxicity of pentachlorobenzene and hexachlorobenzene on the growth of the freshwater microalga Chlorella pyrenoidosa. The authors linked these toxicity changes to complex relationships between organic matter and chlorine substitutions of chlorobenzenes promoting or inhibiting their passage into the cells. In our study, three 
hypotheses could perhaps explain the results. The first hypothesis is that herbicides could be adsorbed on specific DOM substances such as humic compounds (Campbell et al., 1997; Millour, 2011; Vigneault, 2000), that are less consumed/used in diatom cultures than in chlorophyte cultures (by microalgae and/or bacteria), which could explain the lesser toxicity to $C$. calcitrans than to T. suecica. The second hypothesis could be linked to the difference in the nature and composition of cell walls. The cell wall of chlorophytes is in direct contact with herbicides and DOM substances in contrast to that of diatoms, which have siliceous walls (frustule) covered in an organic coating (Round et al., 2007; Tesson and Hildebrand, 2013) that could have a protective role. Indeed, this organic coating could favour the adsorption of irgarol to diatoms, linked to organic molecules on the cell wall (which would explain the greater decrease in irgarol concentration), but inhibit internalization, in a manner that does not occur in T. suecica. Parent et al. (1996) showed that fulvic acids increased the membrane permeability of Chlorella pyrenoidosa (Chlorophyta). Therefore, we hypothesize that this phenomenon of increased membrane permeability, which would facilitate the passage of herbicides (adhered to the wall in our treatments without DOM), could have happened for T. suecica and not for C. calcitrans or to a lesser extent. Measurements of membrane permeability (Parent et al., 1996) and the determination of the partition of herbicides between free and bound to DOM $\left(\log \mathrm{K}_{\mathrm{DOC}}\right)$, would be necessary to answer this. Finally, the third hypothesis concerns the decrease of herbicide effects, especially for irgarol, on $C$. calcitrans in the presence of DOM. Our hypothesis is that this species could consume DOM constituents directly or indirectly (through the action of bacteria) more efficiently than $T$. suecica, using them as an additional source of energy (e.g. carbon, glucose, vitamins) and would allocate a part of this extra energy (not available without DOM) to detoxification. Indeed, microalgae have enzymatic equipment such as cytochrome P450 (Mthakathi et al., 2015; Thies et al., 1996) or antioxidant enzymes (e.g. superoxide dismutase, catalase; Liu et al., 2017), and can synthesize protective substances (such as carotenoids; Demmig-Adams, 1990; Rowan, 1989). To confirm this last hypothesis, complementary analyses would be needed, such as measurement of enzymatic activity in conditions with and without DOM (Liu et al., 2017).

The toxic effects of I0.5 and M2 were accompanied by a strong increase in the level of extracellular carbon produced per cell over time compared with controls (up to $+855 \%$ for $T$. suecica exposed to M2). This carbon increase, as observed by Bester et al. (1995), likely corresponded to excretion or secretion by cells, reflecting stress or cell wall damage, rather than cell death. It was not accompanied by changes in DOM aromaticity (there was no significant difference in $\triangle \mathrm{SUVA}_{254}$ or HIX between control and herbicide-exposed cultures). On the one hand, it can be hypothesized that the microalgae in controls and treatments I0.5 and M2 secreted the same proportion of aromatic and fluorescent molecules and/or that the consumption of DOM by bacteria was the same. On the other hand, this increase of carbon was accompanied by a modification of average molecular weight $\left(S_{R}\right)$ and DOM humification/aromaticity (HIX) not observed in conditions without DOM. Indeed, the decrease in average molecular weight seemed lower in I0.5 and M2 than in controls, and DOM aromaticity increased over time for T. suecica exposed to I0.5 and M2 and for C. calcitrans exposed to mixture M2, while it decreased in the controls. These results could be explained by an excretion/secretion of more humified molecules with a higher molecular weight than in the controls, a secretion of more reactive molecules and/or a less efficient consumption by the bacteria and microalgae. Complementary analyses on the nature of excreted molecules would be necessary to validate these hypotheses. 
As a whole, the results show that DOM stimulated growth of microalgae slightly for T. suecica and strongly for C. calcitrans, as well as their excretion (as indicated by the plus signs in Figure 5B and D), compared with controls (indicated by zeros in Figure 5B and D). The presence of natural DOM in the cultures profoundly modified the biological and chemical responses of microalgae exposed to $0.5 \mu \mathrm{g} . \mathrm{L}^{-1}$ irgarol and to the mixture M2. The exposure of the two species to the herbicides without DOM induced an inhibition of the biological parameters together with a higher production of DOC and more humified molecules of higher molecular weight (as indicated by the bold minus signs in Figure 5B and narrow minus signs in Figure 5D). When DOM was added to the $T$. suecica cultures, the overall effects were amplified (as indicated by the bold minus signs in Figure 5D). In contrast, for C. calcitrans the effects with DOM were lower: growth was less affected, with a lower excretion closer to control values (as indicated by the narrow minus signs in Figure 5B). However, due to the non-axenic environment of the present study, the possible contribution of bacteria to this toxicity modulation still needs to be investigated.

\section{Conclusions}

The aim of this study was to investigate the influence of natural DOM on the toxicity of three herbicides (irgarol, diuron and S-metolachlor), singly and in mixtures, to two marine microalgae, Chaetoceros calcitrans and Tetraselmis suecica. The concentrations (herbicides and DOM) tested in this study are representative of those found in natural environments under anthropogenic pressure. Results showed that, for both species, irgarol has the most toxic effect on growth, relative intracellular lipid content and operational photosynthetic efficiency, and the differential excretion in terms of composition and quantity of dissolved organic carbon, compared with controls, could be related to this toxicity. They also showed that (i) microalgae are likely able to use molecules present in natural DOM directly or indirectly (made available in non-axenic conditions by bacterial metabolism), (ii) addition of DOM to cultures modulates herbicide toxicity, and (iii) this toxicity modulation is speciesdependent: the toxicity decreases for the diatom, but increases for the chlorophyte. This study therefore highlights the importance of considering DOM as a possible major factor involved in toxicity modulation in the environment.

\section{Acknowledgements}

This study was carried out with financial support from the French National Research Agency (ANR) in the framework of the Investments for the Future Programme, within the Cluster of Excellence COTE (ANR-10LABX-45).

We would like to thank Larissa Haugarreau (Ifremer) for her help with sampling and filtration during the two experiments and, Julie Guéguen (Irstea) for her help with the R software.

\section{References}

AFNOR, 2001. Water quality - Determination of soluble silicates - Molecular absorption spectrometric method NF T 90-007.

Amiard, J.C., 2011. Les risques chimiques environnementaux: Méthodes d'évaluation et impacts sur les organismes. Tec \& doc-Lavoisier, Paris, France.

Amin, S.A., Hmelo, L.R., van Tol, H.M., Durham, B.P., Carlson, L.T., Heal, K.R., Morales, R.L., Berthiaume, C.T., Parker, M.S., Djunaedi, B., Ingalls, A.E., Parsek, M.R., Moran, M.A., Armbrust, E.V., 2015. 
Interaction and signalling between a cosmopolitan phytoplankton and associated bacteria. Nature 522, 98101.

Bao, V.W.W., Leung, K.M.Y., Qiu, J.-W., Lam, M.H.W., 2011. Acute toxicities of five commonly used antifouling booster biocides to selected subtropical and cosmopolitan marine species. Marine Pollution Bulletin 62, 1147-1151.

Bejarano, A.C., Chandler, G.T., Decho, A.W., 2005. Influence of natural dissolved organic matter (DOM) on acute and chronic toxicity of the pesticides chlorothalonil, chlorpyrifos and fipronil on the meiobenthic estuarine copepod Amphiascus tenuiremis. Journal of Experimental Marine Biology and Ecology 321, 4357.

Belles, A., 2012. Développement et applications environnementales des échantillonneurs passifs pour la surveillance des écosystèmes aquatiques. Université de Bordeaux 1, France, p. 470.

Benner, R., 2003. Molecular indicators of the bioavailability of dissolved organic matter, in: Findlay, S.E.G., Sinsabaugh, R.L. (Eds.), Aquatic ecosystems: Interactivity of dissolved organic matter. Academic Press, pp. 121-137.

Bester, K., Hühnerfuss, H., Brockmann, U., Rick, H.J., 1995. Biological effects of triazine herbicide contamination on marine phytoplankton. Archives of Environmental Contamination and Toxicology 29, 277-283.

Boehlert, G.W., Mundy, B.C., 1988. Roles of behavioral and physical factors in larval and juvenile fish recruitment to estuarine nursery areas, American Fisheries Society Symposium, pp. 1-67.

Borowitzka, M.A., Beardall, J., Raven, J.A., 2016. The physiology of microalgae. Springer International Publishing.

Buma, A.G.J., Sjollema, S.B., van de Poll, W.H., Klamer, H.J.C., Bakker, J.F., 2009. Impact of the antifouling agent Irgarol 1051 on marine phytoplankton species. Journal of Sea Research 61, 133-139.

Campbell, P.G., Twiss, M.R., Wilkinson, K.J., 1997. Accumulation of natural organic matter on the surfaces of living cells: implications for the interaction of toxic solutes with aquatic biota. Canadian Journal of Fisheries and Aquatic Sciences 54, 2543-2554.

Caquet, T., Roucaute, M., Mazzella, N., Delmas, F., Madigou, C., Farcy, E., Burgeot, T., Allenou, J.-P., Gabellec, R., 2013. Risk assessment of herbicides and booster biocides along estuarine continuums in the Bay of Vilaine area (Brittany, France). Environmental Science and Pollution Research 20, 651-666.

Cedergreen, N., Kudsk, P., Mathiassen, S.K., Streibig, J.C., 2007. Combination effects of herbicides on plants and algae: do species and test systems matter? Pest Management Science 63, 282-295.

Chaumet, B., Bernard, M., Moreira, A., Morin, S., Mazzella, N., 2016. Diuron uptake by microbial biofilms. , 9th European Conference on Pesticides and Related Organic Micropollutants in the Environment, 15th Symposium on Chemistry and Fate of Modern Pesticides, Santiago de Compostella, Spain.

Chesworth, J.C., Donkin, M.E., Brown, M.T., 2004. The interactive effects of the antifouling herbicides irgarol 1051 and diuron on the seagrass Zostera marina (L.). Aquatic Toxicology 66, 293-305.

Chrétiennot-Dinet, M., 1990. Atlas du phytoplancton marin: chlorarachniophycées, chlorophycées, cryptophycées, euglenophycées, eustigmatophycées, prasinophycées, prymnésiophycées, rhodophycées et tribophycées. Centre National de la Recherche Scientifique (CNRS), Paris.

Coquillé, N., Jan, G., Moreira, A., Morin, S., 2015. Use of diatom motility features as endpoints of metolachlor toxicity. Aquatic Toxicology 158, 202-210.

Cozic, V., Durand, G., 2013. Mission d'étude pour réduire les impacts du carénage sur le milieu marin - Rapport phase 2 : Evaluer les équipements existants (cales et aires de carénage avec systèmes de traitement). IDHESA Bretagne Océane, p. 76.

Croft, M.T., Lawrence, A.D., Raux-Deery, E., Warren, M.J., Smith, A.G., 2005. Algae acquire vitamin B12 through a symbiotic relationship with bacteria. Nature 438, 90-93.

Croft, M.T., Warren, M.J., Smith, A.G., 2006. Algae Need Their Vitamins. Eukaryotic Cell 5, 1175-1183.

Dagens, N., 2012. Rapport d'étude - Les pratiques phytosanitaires agricoles et non agricoles sur le Bassin d'Arcachon. Réseau Pesticides Bassin d'Arcachon (REPAR), SIBA, p. 73. 
Dauvin, J.-C., Costil, K., Duhamel, S., Hocdé, R., Mouny, P., De Roton, G., Desroy, N., Le Neveu, C., 2002. Patrimoine biologique et chaînes alimentaires, Programme scientifique Seine-Aval. Ifremer/Quae, p. 48.

de Brouwer, J.F.C., de Deckere, E.M.G.T., Stal, L.J., 2003. Distribution of extracellular carbohydrates in three intertidal mudflats in Western Europe. Estuarine, Coastal and Shelf Science 56, 313-324.

Demmig-Adams, B., 1990. Carotenoids and photoprotection in plants: a role for the xanthophyll zeaxanthin. Biochimica et Biophysica Acta (BBA) - Bioenergetics 1020, 1-24.

Devilla, A., Brown, M.T., Donkin, M., Tarran, G.A., Aiken, J., Readman, J.W., 2005. Impact of antifouling booster biocides on single microalgal species and on a natural marine phytoplankton community. Marine Ecology Progress Series 286, 1-12.

Droop, M.R., 2007. Vitamins, phytoplankton and bacteria: symbiosis or scavenging? Journal of Plankton Research 29, 107-113.

Dupraz, V., Coquillé, N., Ménard, D., Sussarellu, R., Haugarreau, L., Stachowski-Haberkorn, S., 2016. Microalgal sensitivity varies between a diuron-resistant strain and two wild strains when exposed to diuron and irgarol, alone and in mixtures. Chemosphere 151, 241-252.

Ebenezer, V., Ki, J.-S., 2013. Quantification of toxic effects of the herbicide metolachlor on marine microalgae Ditylum brightwellii (Bacillariophyceae), Prorocentrum minimum (Dinophyceae), and Tetraselmis suecica (Chlorophyceae). J Microbiol. 51, 136-139.

European Union, E.U., 1998. Directive n98/8/CE concerning the placing of biocidal products on the market. Official Journal of the European Communities 123, 1-63.

FAO, 2003. International code of conduct on the distribution and use of pesticides (revised version: adopted by the hundred and twenty-third session of the FAO Council in november 2002). Food Agriculture Organization (FAO) of the United Nations, Rome.

Fauvelle, V., 2012. Evaluation de la contamination en pesticides des tributaires du Bassin d'Arcachon et développement d'un échantillonneur passif spécifique des herbicides anioniques. Université de Bordeaux 1, France, p. 257.

Findlay, S., Sinsabaugh, R.L., 2003. Aquatic ecosystems: interactivity of dissolved organic matter. 1st (ed), Academic Press, Elsevier Science, United States.

Fuerst, E.P., 1987. Understanding the mode of action of the chloroacetamide and thiocarbamate herbicides. Weed Technology 1, 270-277.

Gailhard, I., 2003. Analyse de la variabilité spatio-temporelle des populations microalgales côtières observées par le REseau de surveillance du PHYtoplancton et des phycotoxines (REPHY). Université de la Méditerranée Aix-Marseille 11, France, p. 293.

Gatidou, G., Thomaidis, N.S., 2007. Evaluation of single and joint toxic effects of two antifouling biocides, their main metabolites and copper using phytoplankton bioassays. Aquatic Toxicology 85, 184-191.

Guillard, R.R.L., 1975. Culture of phytoplankton for feeding marine invertebrates, in: Smith, W.L., Chanley, M.H. (Eds.), Culture of marine invertebrate animals: proceedings -1 st conference on culture of marine invertebrate animals greenport. Springer US, Boston, MA, pp. 29-60.

Guillard, R.R.L., Ryther, J.H., 1962. Studies of marine planktonic diatoms. I. Cyclotella nana Hustedt and Detonula confervacea (Cleve) Gran. Canadian Journal of Microbiology 8, 229-239.

Haitzer, M., Höss, S., Traunspurger, W., Steinberg, C., 1998. Effects of dissolved organic matter (DOM) on the bioconcentration of organic chemicals in aquatic organisms. Chemosphere 37, 1335-1362.

Hall, D.O., Rao, K., 1999. Photosynthesis, 6 ed. Cambridge University Press, 6 ed., Cambridge, United Kingdom.

Hansell, D.A., Carlson, C.A., 2014. Biogeochemistry of marine dissolved organic matter, $2^{\text {nd }}$ ed. Academic Press.

Hellebust, J.A., 1965. Excretion of some organic compounds by marine phytoplankton. Limnology and Oceanography 10, 192-206. 
Helms, J.R., Stubbins, A., Ritchie, J.D., Minor, E.C., Kieber, D.J., Mopper, K., 2008. Absorption spectral slopes and slope ratios as indicators of molecular weight, source, and photobleaching of chromophoric dissolved organic matter. Limnology and Oceanography 53, 955-969.

Herzi, F., 2013. Caractérisation chimique des exsudats du dinoflagellé marin toxique Alexandrium catenella et de la diatomée marine Skeletonema costatum et étude de la réponse protéomique d'Alexandrium catenella en conditions de stress métalliques. Université de Toulon (France); Université de Carthage (Tunisie), p. 308.

Huguet, A., 2007. Mise au point de procédés membranaires pour l'étude de la matière organique dissoute en milieux côtiers. Université de Bordeaux 1, France, p. 313.

Huguet, A., Roux-de Balmann, H., Parlanti, E., 2009a. Fluorescence spectroscopy applied to the optimisation of a desalting step by electrodialysis for the characterisation of marine organic matter. Journal of Membrane Science 326, 186-196.

Huguet, A., Vacher, L., Relexans, S., Saubusse, S., Froidefond, J.M., Parlanti, E., 2009b. Properties of fluorescent dissolved organic matter in the Gironde Estuary. Organic Geochemistry 40, 706-719.

Ihaka, R., Gentleman, R., 1996. R: a language for data analysis and graphics. Journal of computational and graphical statistics 5, 299-314.

Jones, R.J., Kerswell, A.P., 2003. Phytotoxicity of photosystem II (PSII) herbicides to coral. Marine Ecology Progress Series 261, 149-159.

Juneau, P., Dewez, D., Matsui, S., Kim, S.G., Popovic, R., 2001. Evaluation of different algal species sensitivity to mercury and metolachlor by PAM-fluorometry. Chemosphere 45, 589-598.

Karlsson, J., Bystrom, P., Ask, J., Ask, P., Persson, L., Jansson, M., 2009. Light limitation of nutrient-poor lake ecosystems. Nature 460, 506-509.

Kim, B.-H., Ramanan, R., Cho, D.-H., Oh, H.-M., Kim, H.-S., 2014. Role of Rhizobium, a plant growth promoting bacterium, in enhancing algal biomass through mutualistic interaction. Biomass and Bioenergy 69, 95-105.

Koutsaftis, A., Aoyama, I., 2006. The interactive effects of binary mixtures of three antifouling biocides and three heavy metals against the marine algae Chaetoceros gracilis. Environmental Toxicology 21, 432-439.

Kujawinski, E.B., 2011. The impact of microbial metabolism on marine dissolved organic matter. Annual Review of Marine Science 3, 567-599.

Laliberté, G., de la Noüe, J., 1993. Auto-, hetero-, and mixotrophic growth of Chlamydomonas humicola (Chlorophyceae) on acetate. Journal of Phycology 29, 612-620.

Lê, S., Josse, J., Husson, F., 2008. FactoMineR: an R package for multuvariate analysis. Journal of Statistical Software 25, 1-18.

Liu, H., Xia, Y., Cai, W., Zhang, Y., Zhang, X., Du, S., 2017. Enantioselective oxidative stress and oxidative damage caused by Rac- and S-metolachlor to Scenedesmus obliquus. Chemosphere 173, 22-30.

Liu, X., Duan, S., Li, A., Xu, N., Cai, Z., Hu, Z., 2009. Effects of organic carbon sources on growth, photosynthesis, and respiration of Phaeodactylum tricornutum. Journal of Applied Phycology 21, 239-246.

Ma, J., Wang, S., Wang, P., Ma, L., Chen, X., Xu, R., 2006. Toxicity assessment of 40 herbicides to the green alga Raphidocelis subcapitata. Ecotoxicology and Environmental Safety 63, 456-462.

Mai, H., Morin, B., Pardon, P., Gonzalez, P., Budzinski, H., Cachot, J., 2013. Environmental concentrations of irgarol, diuron and S-metolachlor induce deleterious effects on gametes and embryos of the Pacific oyster, Crassostrea gigas. Marine Environmental Research 89, 1-8.

Millour, M., 2011. Interactions entre la matière organique dissoute et les microalgues marines: rapprochement, adhésion et réaction. Université du Québec à Rimouski, Institut des sciences de la mer de Rimouski, Mémoire. Rimouski, Québec, p. 133.

Mitra, A., Zaman, S., 2016. Basics of marine and estuarine ecology. Springer, India. 
Mthakathi, N.T., Kgosiemang, I.K.R., Chen, W., Mohlatsane, M.E., Mojahi, T.J., Yu, J.-H., Mashele, S.S., Syed, K., 2015. Cytochrome P450 monooxygenase analysis in free-living and symbiotic microalgae Coccomyxa sp. C-169 and Chlorella sp. NC64A. Algae 30, 233.

Munaron, D., Tapie, N., Budzinski, H., Andral, B., Gonzalez, J.-L., 2012. Pharmaceuticals, alkylphenols and pesticides in Mediterranean coastal waters: Results from a pilot survey using passive samplers. Estuarine, Coastal and Shelf Science 114, 82-92.

Nagata, T., 2008. Organic matter-bacteria interactions in seawater, in: Kirchman, D.L. (Ed.), Microbial ecology of the oceans, 2 ed. Wiley-Blackwell, pp. 207-242.

Nestler, H., Groh, K.J., Schönenberger, R., Behra, R., Schirmer, K., Eggen, R.I.L., Suter, M.J.F., 2012. Multipleendpoint assay provides a detailed mechanistic view of responses to herbicide exposure in Chlamydomonas reinhardtii. Aquatic Toxicology 110-111, 214-224.

Nicolas, J.-L., Corre, S., Cochard, J.-C., 2004. Bacterial population association with phytoplankton cultured in a bivalve hatchery. Microb Ecol 48, 400-413.

Nimbal, C.I., Yerkes, C.N., Weston, L.A., Weller, S.C., 1996. Herbicidal activity and site of action of the natural product sorgoleone. Pesticide Biochemistry and Physiology 54, 73-83.

Okamura, H., 2002. Photodegradation of the antifouling compounds irgarol 1051 and diuron released from a commercial antifouling paint. Chemosphere 48, 43-50.

Okamura, H., Sugiyama, Y., 2004. Photosensitized degradation of irgarol 1051 in water. Chemosphere 57, 739743.

Parent, L., Twiss, M.R., Campbell, P.G.C., 1996. Influences of natural dissolved organic matter on the interaction of aluminum with the microalga Chlorella: a test of the free-ion model of trace Metal toxicity. Environmental Science \& Technology 30, 1713-1720.

Pesce, S., Batisson, I., Bardot, C., Fajon, C., Portelli, C., Montuelle, B., Bohatier, J., 2009. Response of spring and summer riverine microbial communities following glyphosate exposure. Ecotoxicology and Environmental Safety 72, 1905-1912.

Rajasekaran, G., Murali, K., Nagan, S., Amoudhavally, V., Santhaswaruban, V., 2005. Contaminant transport modeling in marine clays. Ocean Engineering 32, 175-194.

Ramanan, R., Kim, B.-H., Cho, D.-H., Oh, H.-M., Kim, H.-S., 2016. Algae-bacteria interactions: Evolution, ecology and emerging applications. Biotechnology Advances 34, 14-29.

REPAR, 2015. Fiche de vie REPAR - quantifier, connaître, comprendre, susciter et partager. Réseau Pesticides Bassin d'Arcachon (REPAR), p. 96

Roubeix, V., Fauvelle, V., Tison-Rosebery, J., Mazzella, N., Coste, M., Delmas, F., 2012. Assessing the impact of chloroacetanilide herbicides and their metabolites on periphyton in the Leyre River (SW France) via short term growth inhibition tests on autochthonous diatoms. Journal of Environmental Monitoring 14, $1655-1663$

Roubeix, V., Mazzella, N., Méchin, B., Coste, M., Delmas, F., 2011. Impact of the herbicide metolachlor on river periphytic diatoms: experimental comparison of descriptors at different biological organization levels. Annales de Limnologie - International Journal of Limnology 47, 239-249.

Round, F.E., Crawford, R.M., Mann, D.G., 2007. Diatoms: biology and morphology of the genera. Cambridge University Press.

Rowan, K.S., 1989. Photosynthetic pigments of algae. Cambridge University Press.

Sakkas, V.A., Lambropoulou, D.A., Albanis, T.A., 2002. Photochemical degradation study of irgarol 1051 in natural waters: influence of humic and fulvic substances on the reaction. Journal of Photochemistry and Photobiology A: Chemistry 147, 135-141.

Schmalfuß, J., Matthes, B., Mayer, P., Böger, P., 1998. Chloroacetamide mode of action, I: Inhibition of very long chain fatty acid synthesis in Scenedesmus acutus. Zeitschrift Fur Naturforschung C 53, 995-1003.

Sjollema, S.B., MartínezGarcía, G., van der Geest, H.G., Kraak, M.H.S., Booij, P., Vethaak, A.D., Admiraal, W., 2014. Hazard and risk of herbicides for marine microalgae. Environmental Pollution 187, 106-111. 
SOeS, 2015. Les pesticides dans les cours d'eau français en 2013, Chiffres \& statististiques. Commissariat général au développement durable - Service de l'observation et des statistiques, p. 12.

Tapie, N., Thévand, A., Chevance-Demars, L., Pardon, P., Jeandenand, S., Budzinski, H., 2016. Le REseau de Surveillance des Pesticides sur le Bassin d'Arcachon (REPAR), 46e congrès du Groupe Français des Pesticides (GFP), Bordeaux, p. 1.

Taylor, C., Matzke, M., Kroll, A., Read, D.S., Svendsen, C., Crossley, A., 2016. Toxic interactions of different silver forms with freshwater green algae and cyanobacteria and their effects on mechanistic endpoints and the production of extracellular polymeric substances. Environmental Science: Nano 3, 396-408.

Tesson, B., Hildebrand, M., 2013. Characterization and localization of insoluble organic matrices associated with diatom cell walls: insight into their roles during cell wall formation. PLoS ONE 8, e61675.

Tetko, I.V., Gasteiger, J., Todeschini, R., Mauri, A., Livingstone, D., Ertl, P., Palyulin, V.A., Radchenko, E.V., Zefirov, N.S., Makarenko, A.S., Tanchuk, V.Y., Prokopenko, V.V., 2005. Virtual computational chemistry laboratory - design and description. Journal of Computer-Aided Molecular Design 19, 453-463.

Thakkar, M., Randhawa, V., Wei, L., 2013. Comparative responses of two species of marine phytoplankton to metolachlor exposure. Aquatic Toxicology 126, 198-206.

Thies, F., Backhaus, T., Bossmann, B., Grimme, L.H., 1996. Xenobiotic biotransformation in unicellular green algae (involvement of cytochrome $\mathrm{P} 450$ in the activation and selectivity of the pyridazinone pro-herbicide metflurazon). Plant Physiology 112, 361-370.

Urbani, R., Sist, P., Pletikapić, G., Mišić Radić, T., Svetličić, V., Žutić, V., 2012. Diatom Polysaccharides: Extracellular Production, Isolation and Molecular Characterization, The Complex World of Polysaccharides, pp. 345-367.

Vigneault, B., 2000. Interactions des substances humiques dissoutes avec les algues unicellulaires: mécanismes et implications, Institut national de la recherche scientifique. Université du Québec, Canada, Québec, p. 164.

Weishaar, J.L., Aiken, G.R., Bergamaschi, B.A., Fram, M.S., Fujii, R., Mopper, K., 2003. Evaluation of specific ultraviolet absorbance as an indicator of the chemical composition and reactivity of dissolved organic carbon. Environmental Science \& Technology 37, 4702-4708.

Wetzel, R.G., 2001. Limnology: lake and river ecosystems, Third ed. 3rd (ed) Academic Press, Elsevier Science, San Diego, (CA), United States, p. 1006.

Windler, M., Bova, D., Kryvenda, A., Straile, D., Gruber, A., Kroth, P.G., 2014. Influence of bacteria on cell size development and morphology of cultivated diatoms. Phycological Research 62, 269-281.

Zhang, N., Xu, B., Qi, F., 2016a. Effect of phosphate loading on the generation of extracellular organic matters of Microcystis aeruginosa and its derived disinfection by-products. Water, Air, \& Soil Pollution 227, 264.

Zhang, S., Lin, D., Wu, F., 2016b. The effect of natural organic matter on bioaccumulation and toxicity of chlorobenzenes to green algae. Journal of Hazardous Materials 311, 186-193.

Zsolnay, A., Baigar, E., Jimenez, M., Steinweg, B., Saccomandi, F., 1999. Differentiating with fluorescence spectroscopy the sources of dissolved organic matter in soils subjected to drying. Chemosphere 38, 45-50. 


\section{Figure captions}

Figure 1: Herbicide concentrations in the highest treatments of irgarol (A), diuron (B) and S-metolachlor (C), singly and in mixture M2, in abiotic and biotic components on the first and last days of the experiments. All values are mean values ( \pm standard error, $S E)$. Abiotic means $(n=2)$ without DOM include the non-DOM abiotic systems from each experiment (one from the $C$. calcitrans experiment and one from the $T$. suecica experiment); abiotic means with DOM $(\mathrm{n}=4)$ include the DOM abiotic systems from both experiments (two from the $C$. calcitrans experiment and two from the $T$. suecica experiment). For the biotic systems, $\mathrm{n}=3$. $\dagger$ indicates significant differences between biotic and abiotic conditions on day 0 and * indicates significant differences between day 0 and day 6 for a given treatment ( $\mathrm{t}$-test, $*$ and $\dagger \mathrm{p}<0.05)$. The numeric value indicates the $\beta$ value.
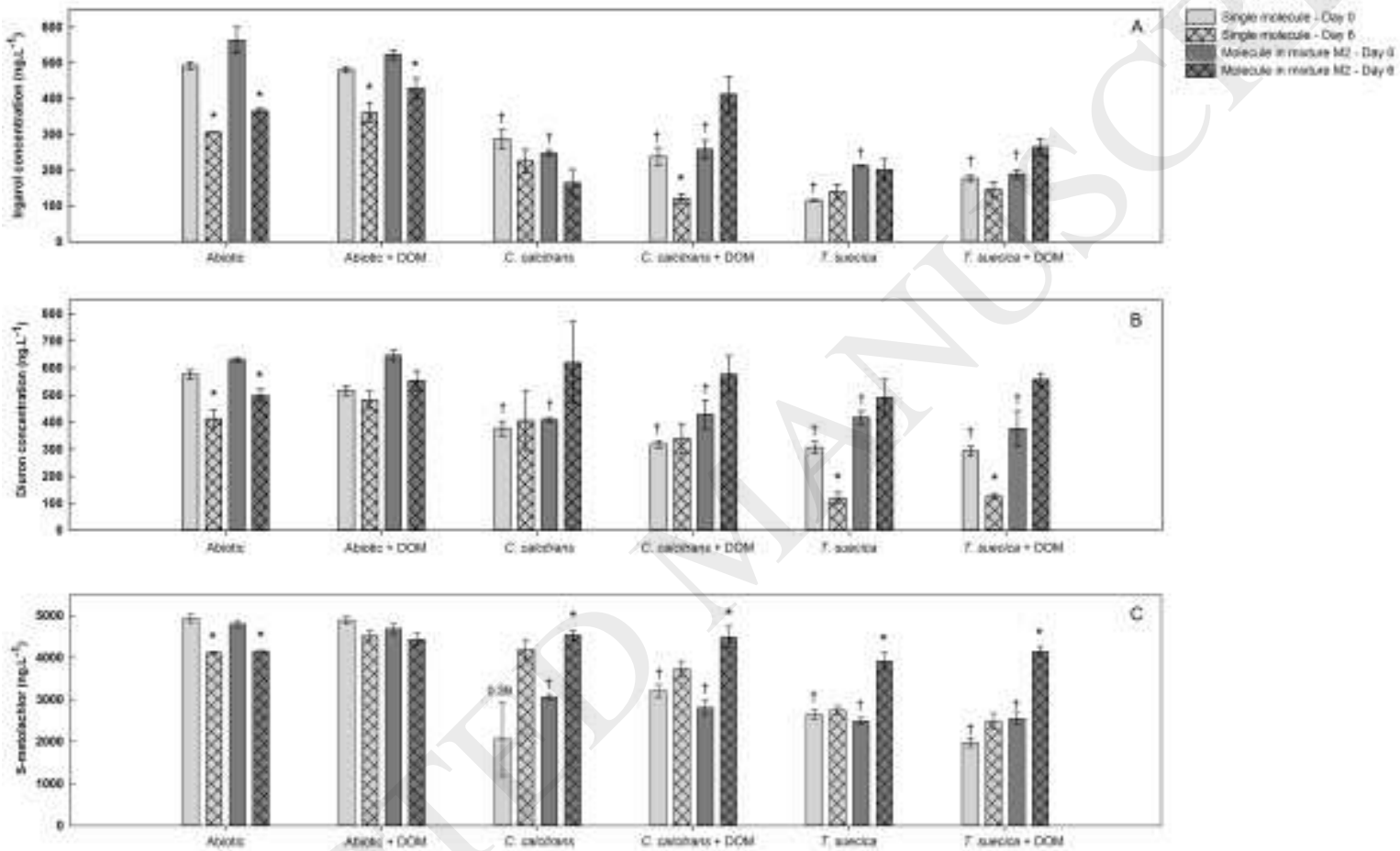

Figure 2: Mean ( \pm SE) concentrations of nitrates, orthophosphates and silicates on the first (Day 0) and last days of experiments for C. calcitrans (A, B and C) and T. suecica (D) without DOM (white bars) and with DOM (grey bars) for all biotic cultures: control, irgarol at 0.05 (I0.05) and 0.5 (I0.5) $\mu$ g.L ${ }^{-1}$, diuron at 0.05 (D0.05) and 0.5 (D0.5) $\mu \mathrm{g} . \mathrm{L}^{-1}$, S-metolachlor at 0.5 (S0.5) and 5 (S5) $\mu \mathrm{g} . \mathrm{L}^{-1}$ and the mixtures: M1 (I0.05+D0.05+S0.5) and $\mathrm{M} 2\left(\mathrm{I} 0.5+\mathrm{D} 0.5+\mathrm{S} 5\right.$ ) (for $\mathrm{NO}_{3}{ }^{-}$and $\mathrm{PO}_{4}{ }^{-}$on the last day, $\mathrm{n}=4$ for controls and $\mathrm{n}=3$ for herbicide-exposed cultures; otherwise $\mathrm{n}=1)$. * and $†$ indicate significant differences (t-test, $\mathrm{p}<0.05)$ between controls and herbicide-exposed treatments for conditions without DOM and with DOM, respectively. The numeric values indicate $\beta$ values. 

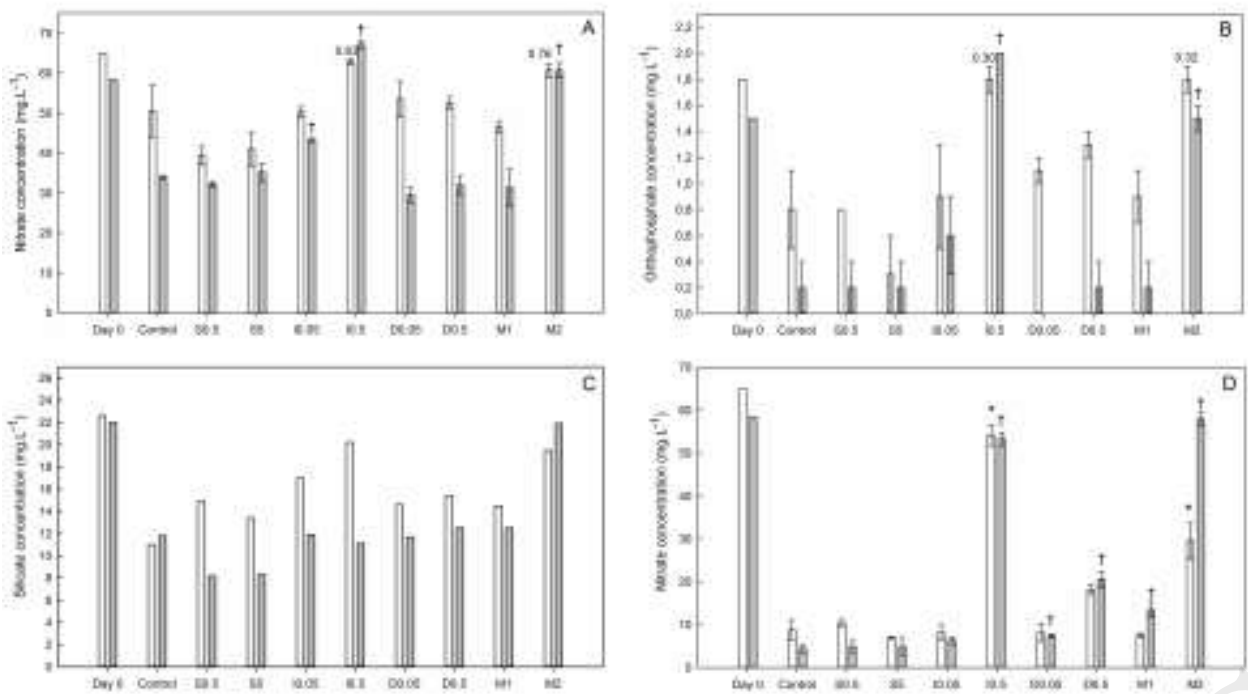

Figure 3: Percentage variation in biological endpoints (mean $\pm \mathrm{SE}$ ) of $C$. calcitrans cultures (A) and T. suecica cultures (B) exposed to herbicides, compared with their respective controls (without and with DOM). Only significant effects (ANOVAs, $\mathrm{p}<0.05)$ on growth rate $(\mu)$, relative lipid content $\left(\mathrm{FL} 1_{\text {Lipids }}\right)$ and photosynthetic efficiency ( $\left.\Phi^{\prime}{ }_{M}\right)$ after exposure to irgarol (I) at 0.05 (I0.05) and 0.5 (I0.5) $\mu \mathrm{g} . \mathrm{L}^{-1}$, diuron (D) at 0.05 (D0.05) and 0.5 (D0.5) $\mu \mathrm{g} . \mathrm{L}^{-1}$ and S-metolachlor (S) at 0.5 (S0.5) and 5 (S5) $\mu \mathrm{g} . \mathrm{L}^{-1}$, alone and in mixtures (M: M1 $(\mathrm{I} 0.05+\mathrm{D} 0.05+\mathrm{S} 0.5)$ and $\mathrm{M} 2(\mathrm{I} 0.5+\mathrm{D} 0.5+\mathrm{S} 5))$ are shown. Negative values correspond to inhibition, while positive values indicate stimulation, compared with the controls.

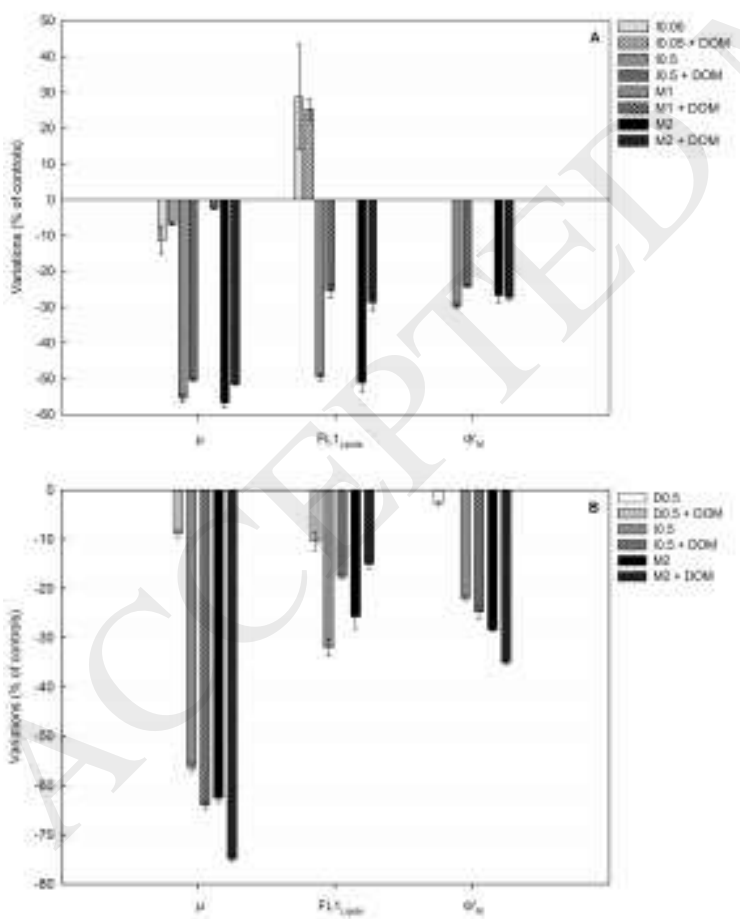

Figure 4: Evolution, over the experiments $(\Delta)$, of dissolved organic carbon concentration (DOC, in pgC.cell ${ }^{-1} ; \mathrm{A}$ and B), SUVA $A_{254}$ (in L.mgC ${ }^{-1} \cdot \mathrm{m}^{-1} ; \mathrm{C}$ and $\mathrm{D}$ ) and $\mathrm{S}_{\mathrm{R}}\left(\mathrm{E}\right.$ and F) parameters for controls, I0.5 (irgarol at $0.5 \mu \mathrm{g} . \mathrm{L}^{-1}$ ) and $\mathrm{M} 2$ (irgarol at $0.5 \mu \mathrm{g} . \mathrm{L}^{-1}+$ diuron at $0.5 \mu \mathrm{g} . \mathrm{L}^{-1}+\mathrm{S}$-metolachlor at $5 \mu \mathrm{g} . \mathrm{L}^{-1}$ ) treatments in C. calcitrans (A, C 
and E) and T. suecica (B, D and F) cultures without DOM (white bars) and with DOM (grey bars). All values are the mean change between day $0(n=1)$ and day $6(n=4$ for controls and $n=3$ for I0.5 and M2, \pm SE). * and $\dagger$ indicate significant differences ( $\mathrm{t}$-test, $\mathrm{p}<0.05)$ between controls and cultures exposed to herbicides in conditions without DOM and with DOM addition, respectively. The numeric values indicate $\beta$ values.
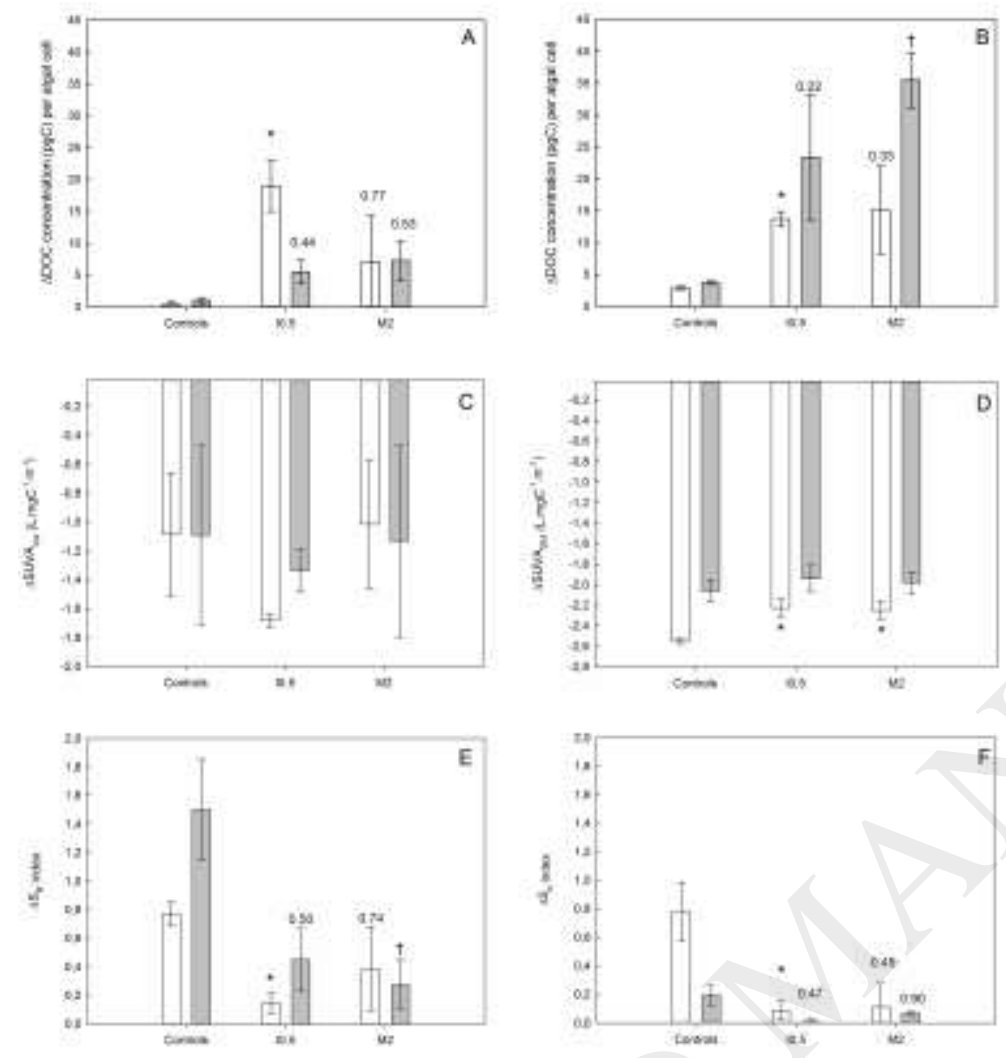

Figure 5: Principal component analyses (PCA) illustrating the relationships between biological ( $\mu$ : growth rate; FL1 Lipids: relative intracellular lipid content; Yield: photosynthetic efficiency) and chemical parameters characterizing DOM evolution over the experiments $(\triangle \mathrm{DOC}$ : concentration of dissolved organic carbon per cell; $\triangle \mathrm{SR}$ : spectral slope ratio; $\triangle \mathrm{HIX}$ : humification index; $\triangle$ SUVA254: specific UV absorbance ratio) in control (C), I0.5 (irgarol at $0.5 \mu \mathrm{g} . \mathrm{L}^{-1}$ ) and M2 (irgarol at $0.5 \mu \mathrm{g} . \mathrm{L}^{-1}+$ diuron at $0.5 \mu \mathrm{g} . \mathrm{L}^{-1}+$ S-metolachlor at $5 \mu \mathrm{g} . \mathrm{L}^{-1}$ ) treatments in conditions with and without DOM for C. calcitrans (A and B) and T. suecica (C and D) cultures. Only parameters statistically affected by herbicides were used for analyses. A and C correspond to the factor map of variables on the two first axes. B and D correspond to the projection of individuals; arrows and signs (plus, minus and "0") were added afterwards in order to symbolize the overall trends observed in the biological and chemical parameters. 

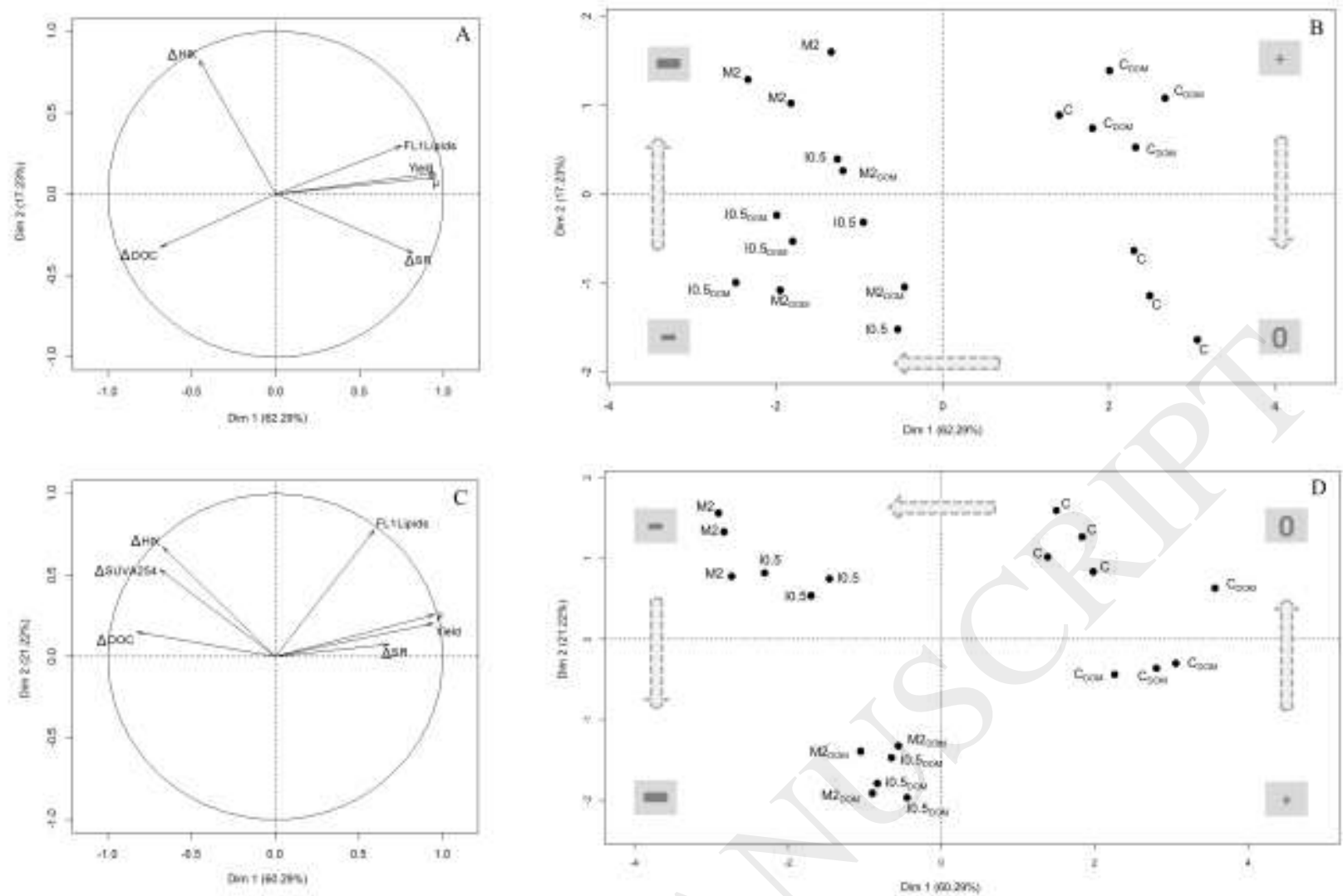
Table 1 - Growth rate $(\mu)$, relative intracellular lipid content (FL1 Lipids ratio) and operational yield $\left(\Phi^{\prime}{ }_{M}\right)$ obtained on the last day of experiments for control cultures of $C$. calcitrans and $T$. suecica with and without DOM. All values are mean values $( \pm$ standard error, $S E ; n=4)$ and * indicates significant differences between treatments (t-test, $* \mathrm{p}<0.05 ; * * \mathrm{p}<0.01 ; * * * \mathrm{p}<0.001)$. The values in brackets indicate $\beta$ values.

\begin{tabular}{ccccc} 
& \multicolumn{2}{c}{ Chaetoceros calcitrans } & \multicolumn{2}{c}{ Tetraselmis suecica } \\
\cline { 2 - 5 } & Without DOM & With DOM & Without DOM & With DOM \\
\hline$\mu\left(\mathrm{h}^{-1}\right)$ & $0.035 \pm 0.000$ & $0.038 \pm 0.000 * * *$ & $0.026 \pm 0.001$ & $0.026 \pm 0.000$ \\
FL1 Lipids ratio & $248 \pm 20$ & $153 \pm 5 * *$ & $75 \pm 3$ & $79 \pm 2(0.84)$ \\
$\Phi^{\prime}{ }_{M}$ & $0.76 \pm 0.01$ & $0.74 \pm 0.00(0.78)$ & $0.78 \pm 0.00$ & $0.78 \pm 0.00$ \\
\hline
\end{tabular}


Table 2 - Evolution $(\Delta)$ of DOM fluorescence parameters (HIX: humification index and BIX: biological index) between the last and first days of experiments for controls, I0.5 (irgarol at $0.5 \mu \mathrm{g} . \mathrm{L}^{-1}$ ) and M2 (irgarol at $0.5 \mu \mathrm{g} . \mathrm{L}^{-1}+$ diuron at $0.5 \mu \mathrm{g} . \mathrm{L}^{-1}+\mathrm{S}$-metolachlor at $5 \mu \mathrm{g} . \mathrm{L}^{-1}$ ) treatments. All values are mean variations between day $6(\mathrm{n}=4$ for controls and $\mathrm{n}=3$ for $\mathrm{I} 0.5$ and M2 \pm standard error) and day $0(\mathrm{n}=1) . *$ indicates significant differences with their respective controls $\left(\mathrm{t}\right.$-test, $\left.{ }^{*} \mathrm{p}<0.05 ; * * \mathrm{p}<0.01\right)$. The values in brackets indicate $\beta$ values.

\begin{tabular}{|c|c|c|c|c|c|}
\hline & & \multicolumn{2}{|c|}{ Chaetoceros calcitrans } & \multicolumn{2}{|c|}{ Tetraselmis suecica } \\
\hline & & Without DOM & With DOM & Without DOM & With DOM \\
\hline & Controls & $-0.37 \pm 0.15$ & $-0.76 \pm 0.40$ & $-1.11 \pm 0.06$ & $-0.54 \pm 0.10$ \\
\hline$\Delta \mathrm{H}$ & $\mathrm{I} 0.5$ & $-0.37 \pm 0.06$ & $-0.55 \pm 0.26(0.95)$ & $-1.07 \pm 0.08$ & $0.44 \pm 0.17 * *$ \\
\hline & M2 & $-0.62 \pm 0.11(0.81)$ & $0.66 \pm 0.14 *$ & $-1.01 \pm 0.06(0.86)$ & $0.58 \pm 0.23 * *$ \\
\hline & Controls & $0.11 \pm 0.01$ & $0.10 \pm 0.03$ & $-0.04 \pm 0.05$ & $0.01 \pm 0.01$ \\
\hline$\Delta \mathrm{BIX}$ & I0.5 & $0.10 \pm 0.01$ & $0.06 \pm 0.01(0.65)$ & $-0.02 \pm 0.01$ & $0.01 \pm 0.00$ \\
\hline & M2 & $0.08 \pm 0.01(0.70)$ & $0.06 \pm 0.01(0.65)$ & $-0.03 \pm 0.01$ & $0.01 \pm 0.00$ \\
\hline
\end{tabular}

